\title{
DETERMINANTS OF COLLATERAL
}

\section{4}

Gabriel Jiménez

Vicente Salas

Jesús Saurina

Documentos de Trabajo

N. 0420

BANCODE ESPANAA

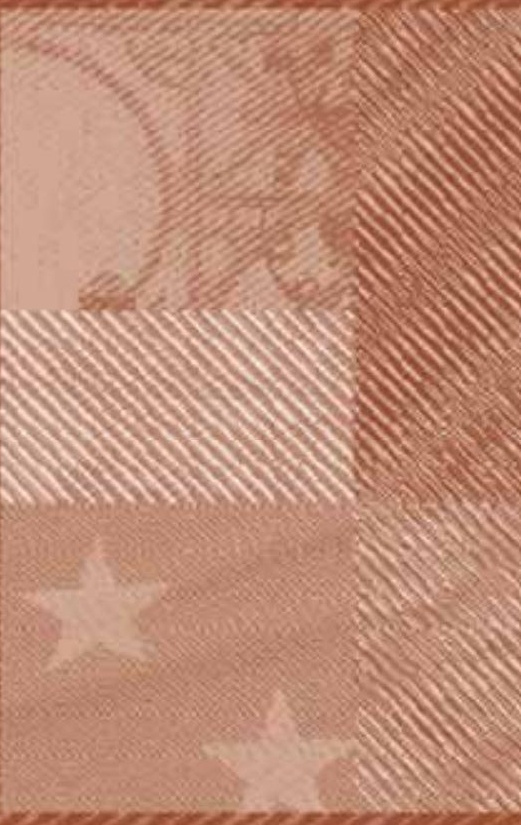


DETERMINANTS OF COLLATERAL 
DETERMINANTS OF COLLATERAL

\author{
Gabriel J iménez
}

BANCO DE ESPAÑA

Vicente Salas

UNIVERSIDAD DE ZARAGOZA AND BANCO DE ESPAÑA

J esús Saurina

BANCO DE ESPAÑA

$\left(^{\star}\right)$ Address for correspondence: Jesús Saurina; C/Alcalá 48, 28014 Madrid, Spain. Tlf: + 3491338 5080; e-mail: jsaurina@bde.es

$\left.{ }^{(* *}\right)$ This paper is the sole responsibility of its authors and the views presented here do not necessarily reflect those of the Banco de España. We much appreciate the detailed comments made by an anonymous referee and Julio Segura, which have helped us to improve the paper significantly. Moreover, we thank everyone at a CEMFI seminar for their numerous comments and suggestions, in particular, M. Arellano, S. Bentolila, O. Bover and R. Repullo. Comments from participants at the Second International Conference on Credit Risk held in Montréal, in particular, those from E. Altman, J. Dermine and M. Levonian as well as those from K. Roszbach and participants at the European Finance Association meeting in Maastritch were likewise gratefully received. We also thank A. Almazán for his comments to preliminary versions of this paper. Any errors that remain are, however, entirely the authors' own. 
The Working Paper Series seeks to disseminate original research in economics and finance. All papers have been anonymously refereed. By publishing these papers, the Banco de España aims to contribute to economic analysis and, in particular, to knowledge of the Spanish economy and its international environment.

The opinions and analyses in the Working Paper Series are the responsibility of the authors and, therefore, do not necessarily coincide with those of the Banco de España or the Eurosystem.

The Banco de España disseminates its main reports and most of its publications via the INTERNET at the following website: http://www.bde.es

Reproduction for educational and non-commercial purposes is permitted provided that the source is acknowledged.

\section{(c) BANCO DE ESPAÑA, Madrid, 2004}

ISSN: 0213-2710 (print)

ISSN: 1579-8666 (on line)

Depósito legal:

Imprenta del Banco de España 


\section{Abstract}

This paper investigates the factors that determine the use of collateral in time series and cross-section data on the population of banks' loans to Spanish firms every year from 1984 to 2002 (over two million loans). Using the record of actual loan defaults of borrowers as a measure of credit quality, we find that the use of collateral is higher in loans to low credit quality borrowers. The likelihood of collateral is also higher when the lender is a small bank, when the lender is a savings bank and in loans made in periods of low economic growth. On the other hand, the use of collateral is less likely in loans made to borrowers with longer relationship with the lender and in more concentrated credit markets. A higher risk free interest rate of the economy and a smaller size of the loan increase the likelihood that a loan will be totally secured with collateral instead of partially secured. Overall the result are consistent with theories that explain the use of collateral as a consequence of information asymmetries in credit markets, although the effect of macroeconomic conditions in the use of collateral remains unexplained. 


\section{Introduction}

Collateral is a common term in loan contracts, together with the interest rate, maturity, size and possible covenants. Credit market research explains the use of collateral as a consequence of problems of adverse selection [Besanko and Thakor (1987a and b), Chan and Kanakas (1985), and Bester (1985)], and/or problems of moral hazard [Boot, Thakor, and Udell (1991)], which are present in transactions between borrowers and lenders. The nature of the relationship between borrowers and lenders, transactional or relationship lending [Sharpe (1990), and Boot and Thakor (1994)], the level of competition in the credit market [Besanko and Thakor (1987a)] and the cost/benefits of a thorough screening of borrowers [Manove and Padilla (1999 and 2001)] may also explain why some loans are secured and others are granted without collateral. Besides these theoretical developments, there is a belief that academic research about the role of collateral is limited [John, Lynch, and Puri (2003)] while the empirical literature has not yet settled important issues such as whether collateral is a signal of a riskier or a safer loan, and whether relationship lending lowers or increases the requirements for obtaining a loan. Theories that relate the use of collateral to credit market competition and with the inclinations of lenders to ask for collateral instead of thoroughly screening the borrower have not yet been subject to empirical tests. Nothing is known either on how macroeconomic conditions (the business cycle and the risk-free interest rate of the economy) affect the use of collateral in business loans.

Drawing from existing theories, this paper models the use of collateral to secure a loan as a function of characteristics of the borrower (credit quality), the lender (specialisation), the credit market (competition), the nature of the borrower-lender relationship (duration), the loan (size) and of macroeconomic conditions (business cycle) ${ }^{1}$. The comprehensive model on determinants of collateral is tested with a panel data that contains all financial loans to business firms made by Spanish banks every year from 1984 to 2002, so that tests are performed controlling for borrowers fixed effects and for time varying variables such as macroeconomic conditions. So far, the empirical literature has focused only on partial determinants of collateral such as risk [Berger and Udell (1990)], or relationship lending [Berger and Udell (1995), Harhoff and Körting (1999), and Degrese and van Cayseele (2000)], and in all cases with cross sectional data.

Besides the extension of empirical work to other determinants of the use of collateral not considered before, such as credit market competition [Besanko and Thakor (1987a)], the inclination of lenders to use collateral as a substitute of thorough screening of the borrower [Manove and Padilla (1999 and 2001)] and macroeconomic conditions, the paper provides a new and sharper test of the relationship between use of collateral and credit risk of the borrower.

The unique database, the Credit Register of the Bank of Spain, allows us to group borrowers in three risk classes according to their public record in that Credit Register: those that have had a loan in default at the time they get a new one, those that had never defaulted at the time of the new loan is granted but default in the near future, and, finally, those that do not default at all. This grouping of borrowers provides the appropriate set up to test the theories that link the use of collateral to credit risk of the borrower and information conditions in the credit market. The group that has a public record of past defaults is the group of

1. What follows focuses only on external collateral, i.e. the assets pledged to secure the loan which are external to the firm. The reason for this choice is that casual observation of the database suggests that this is the most frequent form of collateral. But the precise nature of the collateral is not known and the possibility that collateral is, in some cases, internal (the assets pledged as collateral are internal to the firm) can not be totally ruled out. The use of internal collateral has been considered useful in solving asset-substitution problems, Smith and Warner (1979), and in solving Mayers's under-investment problem, Stulz and Johnson (1985). John, Lynch and Puri (2003) show that moral hazard problems affect yields of loans secured with internal collateral. 
observed lower credit quality and the theory predicts that their likelihood of pledging collateral is the highest among all borrowers [Berger and Udell (1990), and Boot, Thakor, and Udell (1991)]. Those borrowers with a clean record of defaults when they get a loan but default afterwards can still belong to the borrowers of observed credit quality if lenders have other information such as accounting data or credit ratings to sort them out. If this is the case the likelihood to pledge collateral among borrowers with first default after their current loan will also be higher than among borrowers of no default at all because lenders ask collateral to borrowers of observed lower quality.

But if credit quality is private information, borrowers with a clean record of defaults that consider themselves of high credit quality can use collateral to signal quality and get a lower interest in their loans [Bester (1985), Besanko and Thakor (1987a and b), Chan and Kanatas (1985), and Chan, Greenbaum, and Thakor (1986)]. If borrowers with a clean record of defaults behave this way among those borrowers that default for the first time after getting the loan, revealing themselves as low quality, the proportion of loans with collateral will be lower than among those that do not default. Therefore if collateral is used to signal credit quality, as theories that explain the use of collateral to solve adverse selection problems predict, then the likelihood of collateral in loans to those that default after the current loan for the first time will be lower than among borrowers with no defaults.

We find that the likelihood of collateral is higher among borrowers of the first and of the second group (borrowers that had defaulted before they get a new loan and borrowers that default for the first time after getting the loan) than among borrowers that never default. This would confirm that the observed risk situation prevails in decisions about the terms of the loans. But we also find that the likelihood of collateral among borrowers who first default after the loan is granted, compared with the likelihood of collateral among borrowers that do not default, is higher in the population of old borrowers, with past loans, than in the population of new ones, those that get a loan for the first time. As it can be expected the lender opportunities to observe the risk of the borrower are higher for older borrowers, and the possibility to use collateral to signal credit quality occurs mainly among young borrowers with no previous record of financial or commercial activity. We interpret the lower likelihood of collateral in loans to new borrowers that default after the loan is granted compared with the likelihood of collateral in loans to old borrowers that default for the first time after the current loan, as evidence that some loans are made under conditions of observed risk and others under conditions of private information, although overall the former prevails over the later.

Other papers have looked at the relation between collateral and risk. In some of them risk is measured by the risk premium in the interest rate of the loan [Berger and Udell (1990), and Degrese and van Cayseele (2000)]. The evidence is mixed since the first paper finds a positive association between collateral and risk premium, while the second a negative one. But, most important, the risk premium in the interest rate can be a measure of the risk of the project to be financed with the loan, while the theory links the use of collateral to the risk of the borrower, not to the risk of the project. Harhoff and Korting (1999) find a positive association between use of collateral and observed (i.e. past) low credit quality of the borrower, but they do not consider future loan behaviour (i.e. future defaults). Finally, Jimenez and Saurina (2004), with the same database used in this paper but with the stock of loans not with the new loans in each period, find that the presence of collateral increases the likelihood that a loan will be in default, but no distinction is made as a function of the age of the borrower.

Section 2 describes the empirical model on the determinants of collateral usage in loans and lays down the main hypothesis to be tested, based upon the theoretical models and previous empirical research. In Section 3 we describe the database, the variables and the methodology followed to test the main hypotheses. The results of the empirical analysis are 
presented in Section 4, while Section 5 contains the discussion of the main empirical findings. The conclusions summarise the paper and highlight its contributions. 


\section{Literature review on the use of collateral in loan contracts and main hypotheses of the paper}

As indicated, theories of collateral refer to information asymmetries between borrowers and lenders, to benefits and costs of relationship lending, to the competitive conditions in the credit market, to the inclination of lenders to substitute collateral in place of a thorough screening of the borrower to secure the loan, and to characteristics of the loan, in order to explain why some loans use collateral and others don't. This section reviews these theories of the determinants of collateral and formulates empirically testable predictions from them, together with extensions to control variables that have interest in their own although no precise theory exists on how they determine the use of collateral. The predictions will be formulated in terms of the observable variables used to evaluate the credit quality of borrowers, the intensity of relationship lending, competition in the credit market, characteristics of lenders and variables used to control for borrowers' unobserved and time varying effects. The list of the variables, their definition and computation is shown in Table 1.

Hypothesis 1. The likelihood of collateral in loans is higher among borrowers of observed lower credit quality

Boot, Thakor, and Udell (1991) show that when lenders can observe the credit quality of the borrowers then low quality borrowers get a loan with collateral and good quality borrowers get loans without collateral. This implies that the likelihood of collateral in loans made to borrowers whose low credit quality is public knowledge, those assigned a value of 1 in the variable DEFAULT $T_{\mathrm{t}-1}$, will be higher than in loans made to borrowers with a clean record of defaults.

Hypothesis 2. Among borrowers of unobserved credit quality (private information) the likelihood of collateral is higher among borrowers of higher credit quality.

This hypothesis is based on the theories that explain the use of collateral to signal good quality by borrowers in situations of adverse selection where borrowers know their credit quality but lenders don't [(Chan and Kanatas (1985), Bester (1985), and Besanko and Thakor (1987a)]. The empirical test of this prediction requires having some information on ex post observed credit quality of the borrowers. We use the variable DEFAULT $T_{t+1}$, that takes the value of 1 if a borrower has a clean record until $t$ but defaults in $t+1$ and 0 otherwise, to identify those borrowers with clean record of defaults when they get a loan but default a year after. If good borrowers use collateral to signal credit quality in $t$, a negative sign for the coefficient of DEFAULT $T_{t+1}$ is expected since the theory predicts that low quality borrowers are less likely to pledge collateral than high quality ones. The problem with this test is that we do not know if borrowers that default in $t+1$ for the first time belong to the group of observed risk or to the group of private information. Most likely there will be a mix of the two situations and the sign of the coefficient of DEFAULT $T_{t+1}$ will depend on which proportion of cases dominates over the other.

The AGE AS BORROWERt 1 is a variable that can help to identify borrowers with different possibilities of being sorted by observed risk or by private information. Young borrowers start with scant information in their commercial and financial records but as time goes experiences accumulate and their records are filled with more information that can be used to calibrate their credit quality. Therefore, the proportion of borrowers that sort themselves as good quality pledging collateral is likely to be higher among young borrowers than among older ones. As borrowers get older the likelihood of being sorted from observed risk increases and therefore the proportion of borrowers sorted by observed risk in $\mathrm{t}$ in the group that default in $t+1$ should increase with age of the borrower. 
The population of borrowers is divided into the group of "old borrowers", those that have had at least a previous loan before the current loan they get in t, and "new borrowers", those borrowers for whom the loan in $t$ is the first one. The theory that explains collateral as a solution to adverse selection problems predicts a lower increase in collateral for those that default in $t+1$ among new borrowers than among old borrowers, if the proportion of loans made under private information is larger in the former than in the later.

Another variable that may help to sort cases where the dominant situation is observed risk from others where the dominant situation is private information, is the maturity of the loan. In long term loans the information advantage of the borrower over the lender is expected to be higher than in short term loans since the lender will be less forward looking than the borrower who will use the loan to finance a long term project. In our empirical analysis loans are grouped in short term and in long term loans and we expect that the results from private information over observed risk will be more relevant in the group of long term loans than in the group of short term loans.

Hypothesis 3. a) The likelihood of collateral decreases with the duration of the relationship between borrower and lender if the benefits of "relationship lending" prevail and increases with it if duration derives into a "hold up" situation. b) The use of collateral decreases with duration only for borrowers whose credit quality is not known at the time the loan is made.

This hypothesis resumes the predictions on the likelihood of collateral from the literature of relationship lending [Boot (2000)]. Boot and Thakor (1994) show that repeated interactions between borrowers and lenders help to build trust and to reduce moral hazard problems. The use of collateral will be less likely as duration increases since collateral is an alternative to trust to solve moral hazard problems [Boot, Thakor, and Udell (1991)]. In addition Berger and Udell (1995) argue that duration permits investment in information to better sort borrowers of different quality and that the reduction in the likelihood of collateral as duration increases can also be attributed to this sorting effect ${ }^{2}$. On the other hand, longer duration would imply higher likelihood of collateral if longer relationships between borrowers and lenders reflect more severe hold up problems [Chan, Kanatas, and Venezia (1989), Sharpe (1990), Rajan (1992), and Farinha and Santos (2002)]. The relationship between the intensity of relationship lending and likelihood of collateral is then an empirical issue since theories give contradictory predictions. So far, the empirical results are also contradictory since Berger and Udell (1995) for the USA and Harhoff and Körting (1998) for Germany find a negative effect of duration in the likelihood of collateral, but Degryse and van Cayseele (2000) for a sample of loans granted by a single Belgian bank find a positive one.

The variable of relationship lending used in this paper to explain the use of collateral is the number of years the lender has had relations with the borrower at the time of the loan, DURATION $\mathrm{t}_{-1}$. If longer relationships derive into higher trust between borrowers and lenders and/or improves the sorting of borrowers in terms of credit quality then a negative effect of DURATION $\mathrm{N}_{\mathrm{jt}-1}$ in the likelihood of collateral is expected. If longer relationships result from a hold up situation then the expected effect is positive. In order to distinguish between trust or better information behind a possible negative effect of length of the relationship in the likelihood of collateral, the effect of DURATION $\mathrm{N}_{\mathrm{t}-1}$ in this likelihood will be evaluated in borrowers of known lower quality when they get a loan (DEAFAULT $T_{t-1}=1$ ), and in the rest of borrowers. If relationship lending is only a way to improve information about the quality of the lender then among those borrowers whose credit quality is known, DEFAULT $T_{t-1}=1$, longer duration should leave intact the likelihood of collateral. This result would be consistent with hypothesis 3b. On the other hand, if relationship lending means more trust and less moral

2. Diamond (1991) and Petersen and Rajan (1994) present models in which the interest rates on the loans decrease over time as lenders learn more about the attributes and decisions of the borrowers. Their results can be partially extended to the case of collateral. 
hazard then longer duration will lower the likelihood of collateral even among low quality borrowers and hypothesis $3 \mathrm{~b}$ will be rejected.

Since duration of the relationship of the borrower with a particular bank will be jointly determined with the number of operations a borrower has with the bank and with the number of banks the borrower is working with, in the paper we test the hypothesis on the variable DURATION $\mathrm{t}_{-1}$ controlling for these two variables, SCOPE $\mathrm{t}_{\mathrm{t}-1}$ and NUMBER OF LENDERS $\mathrm{S}_{\mathrm{t}-1}$, respectively ${ }^{3}$.

Hypothesis 4. a) The likelihood of collateral in loans decreases with the concentration in the credit market. b) The reduction in the likelihood of collateral as a result of longer borrower-lender relationship will be higher (lower) in more concentrated markets if the value of information obtained in the relationship decreases (increases) with competition in the credit market

It is assumed that credit market concentration reduces competition among lenders so hypothesis 4 summarises the effects of credit market competition in the use of collateral. Competition lowers the rents of lenders in all the states of the world so the use of collateral is more likely in competition than in monopoly [Boot and Thakor (2000)]. Hypothesis 4a accounts for this general result. Competition also shortenss the relationship and reduces the incentives to invest in information [Chan, Greenbaum, and Thakor (1986), Diamond (1991), Petersen and Rajan (1995)], although Boot and Thakor (2000) argue that banks respond to higher competition with closer relationship with their clients in order to increase differentiation and loyalty. All this suggests the relevance of controlling for competitive conditions when testing for the effects of relationship lending, since competition will affect the scope and intensity of the relationship. Second, theories predict that the effect of the variable DURATION $\mathrm{t}_{\mathrm{t}-1}$ in the likelihood of collateral will be different in markets with different level of competition since, for the same duration, the investment in information and in creating loyalty will be more or less depending on the level of competition. This discussion implies that the same duration of a borrower-lender relationship will have different effects in the likelihood of collateral depending on the concentration in the credit market. Theories that predict higher investment in borrower specific information in more concentrated, less competitive, credit markets will be consistent with higher reduction in the likelihood of collateral as duration increases in more concentrated credit markets than in less concentrated. If Boot and Thakor (2000) are correct and banks intensify the relationship as competition increases then market concentration will moderate the effect of duration in the likelihood of collateral.

Hypothesis 5. The use of collateral in loans will be more likely if the loan is made by lenders with low expertise in the evaluation of loans operations.

This hypothesis finds its theoretical support in the work of Manove and Padilla (1999 and 2001). Banks with a lower level of expertise (in particular, new entrants in product or regional markets) and with scarce resources to evaluate the economic risk of the loan will have a greater incentive to use collateral as a substitute for such evaluation. Some papers have looked at differences in lending practices among financial intermediaries, taking into account their specialisation [Carey, Post, and Sharpe (1998)] and their ownership structure [Saunders, Strock, and Tavlos (1990), and Gorton and Rosen (1995)]. But the relationship between the type of lender and the collateral decision has not been studied in detail.

3. The scope of the relationship between borrower and lender and the number of lenders can also be considered variables that characterise relationship lending. In principle, more loans with the same bank implies more relationship and more opportunities to strength the relationship and to improve knowledge. As the number of banks a borrower works with increases it means that the relationship between each of them will be weaker. From these arguments we would expect a negative coefficient for SCOPE and a positive coefficient for NUMBER OF LENDERS if benefits of relationship lending are higher than costs. But these two variables can be related to other unobserved characteristics of the borrower, for example credit quality [Petersen and Rajan (1994] or availability of assets to be used as collateral [Farinha and Santos (2002)], so the specific predictions on them would require a more thorough analysis that it is out of the scope of the paper. Their inclusion in the model is mainly justified in terms of having additional control variables. 
Banks in the sample have different degrees of specialisation in financial loans for business firms, different sizes and some types (commercial versus savings banks). Banks more specialised in financial loans and banks of larger size should have a comparative advantage in terms of evaluating the risk of borrowers, and one should expect a lower recourse to the collateral solution than at other banks. Savings banks (non-profit commercial banks) have traditionally concentrated more on loans to households and have only more recently expanded into loans for business firms. Moreover, savings banks are more conservative institutions as they are, in practice, under the control of their managers and workers who are interested in keeping their jobs and avoiding possible financial distress. Therefore, the probability of collateral in a loan should be higher among savings banks than among commercial banks.

Hypothesis 6. The amount of collateral in a loan will increase with the risk free interest rate of the economy and will decrease with the size of the loan.

This hypothesis is about the amount of collateral, once the decision to pledge collateral is already made. Boot, Thakor, and Udell (1991) show that, under moral hazard, once the lender chooses to ask for collateral, the amount of collateral will increase with the real interest rate of the economy, and decrease with the size of the loan and with a reduction in the dissipative cost of the collateral. To increase the amount of collateral instead of translating the increase in the risk-free real interest rate into higher interest on the loan reduces the agency costs of the transaction. Loans of a greater size reduce the amount of collateral because they imply a higher pay-off for the lender in the good states of the world. Boot, Thakor, and Udell (1991) associate a reduction in the dissipative costs of collateral with the maturity of the loan. There is no previous empirical work to explain the amount of collateral using loan level data. This paper tests the effects of the real risk free interest of the economy and of the size of the loan in the amount of collateral, with a new dependent variable that distinguishes between loans with no collateral, loans with partial collateral (more than $50 \%$ of the face value of the loan) and loans totally secured (100\% of the loan collateralised).

Regarding control variables, little is known about the impact of the macroeconomic conditions, such as business cycle or monetary policy, in the decision to pledge collateral and no previous empirical work exists on these potential determinants of the use of collateral. We introduce growth of the gross domestic product, GDP GROWTH $\mathrm{H}_{\mathrm{t}}$, and interest rates, REAL INTEREST RATE , to account for macroeconomic conditions and get first evidence on whether macroeconomic conditions determine the use of collateral and in what direction. The AGE AS BORROWER $\mathrm{t}_{\mathrm{t}-1}$, the number of years since the borrower had the first registered loan, at the beginning of the year when the loan is made, is an additional control variable to properly evaluate the effect of DURATION $\mathrm{N}_{-1}$ as determinant of collateral since the same years with a bank will have different economic implications depending on the number of years the borrower has been active in the loan market. The former variable complements NUMBER OF LENDERS $_{\mathrm{It}-1}$ and SCOPE $\mathrm{E}_{\mathrm{lt}-1}$ as control variables. The amount of debt of the borrower at the time of the new loan, $\mathrm{DEBT}_{1, \mathrm{t}-1, \mathrm{l}}$, is a control variable to properly account for the relative increase in credit risk faced by lenders with a new loan granted as whose amount is given by the variable $\mathrm{SIZE}_{\mathrm{t}}$. DEBT $\mathrm{t}-1$ is also a proxy for the size of the borrower. Many borrowers will conduct business in local markets. To account for this the variables PROVINCE $\mathrm{t}_{\mathrm{t}-1}$ and GEOGRAPHIC RISK $\mathrm{t}_{\mathrm{t}-1}$ are also included in the list of control variables. The first is a dummy variable for each of the fifty Spanish provinces, and the second is the proportion of bad loans over total loans in the province at the time the new loan is made. Differences in technological, productive and marketing conditions across industries in which the firm (borrower) does business may account, at least partially, for possible differences in the risk of the projects that will be financed with the new loan, and for differences in borrowers' economic risks. The 
dummy variable INDUSTRY and the variable PRODUCT/MARKET RISK $\mathrm{t}_{\mathrm{t}-1}$, proportion of bad loans for each of the 11 industries in which firms are grouped, control for these effects.

The hypotheses listed above on the likelihood that a loan will be with collateral are summarised in the following model,

$\operatorname{Pr}\left(\right.$ Collateral $\left._{i j k l t}=1\right)=F\left(a_{0}+a_{1}\right.$ Default $_{l, t-1}+a_{2}$ Default $_{l, t+1}+a_{3}$ Duration $_{j l, t-1}+$

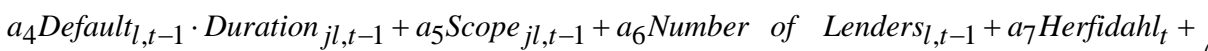
$a_{8}$Herfindahl $_{t} \cdot$ Duration $_{j l, t-1}+a_{9}$ Specialization $_{j t}+a_{10}$ Size of $_{\text {Lender }}{ }_{j t}+a_{11}$ Bank $_{j}+$

$a_{12}$ Control Variables Vijklt ,

where i refers to the loan, $\mathrm{j}$ refers to the bank, $\mathrm{k}$ refers to the market, I refers to firm (borrower) , $t$ refers to the time period (year) and $F($.$) is a distribution function. From the theoretical$ analysis a positive sign is predicted for $\mathrm{a}_{1}$, hypothesis 1 , while the sign of $\mathrm{a}_{2}$ is undetermined although in any case lower among new borrowers and long term loans than among old borrowers and short term loans, respectively (hypothesis 2). The sign of $a_{3}$ is positive if relationship lending evolves into trust and better sorting of borrowers and negative if it evolves into a hold up situation (hypothesis $3 a$ ). The sign of $\mathrm{a}_{4}$ is expected non positive with absolute value greater or equal to $a_{3}$ if duration just means better sorting possibilities and absolute value less than $a_{4}$ if duration implies also more trust in the relationship (hypothesis $3 b$ ). We expect $a_{7}$ negative, hypothesis $4 a$, and the sign of $a_{8}$ will determine if competition in the credit market lowers (positive sign) or increases (negative sign) the incentives to invest in information (hypothesis 4b). A negative sign is predicted for $a_{9}, a_{10}$ and $a_{11}$, hypothesis 5.

Hypothesis 6 will be tested with a model that explains the likelihood of collateral for three values of the dependent variable, no collateral, partial collateral, more than $50 \%$ of the face value of the loan, and full collateral, $100 \%$ face value of the loan. The predictions from the theory will be limited to two variables, the risk free interest rate of the economy and the size of the loan. Higher interest rates are expected to increase more the likelihood of total collateral than of partial collateral, while an increase in the size of the loan is expected to increase more the likelihood of partial collateral than of total collateral. 


\subsection{Database}

The database used in this paper is the Credit Register (Central de Información de Riesgos, CIR of the Banco de España). We focus on all new financial loans above 6,000 euros with a maturity of one year or more ${ }^{4}$ granted by any Spanish commercial or savings bank to legal persons every year during the time-period between December 1984 and December 2002. The reason for concentrating only on financial loans, and excluding other debt operations such as commercial loans, leasing, factoring operations and off-balance sheet commitments is homogeneity and the belief that such loans are more suitable for relationship banking. Nevertheless, financial loans are the bulk of loans to firms since they represent $60 \%$ of the total number of loans in the CIR.

Loans in the database are split into two groups: short-term (maturing at one to three years) and long-term (more than three years). As indicated above, this distinction is in order to have more homogenous operations within each of the two samples, taking into account the observed differences in the frequency with which collateral is used in each of the samples $(8 \%$ and $50 \%$, respectively). A second classification of the loans relates to the experience of the borrower. One group of loans, labelled "old", contains those loans from borrowers about whom, at the time the loan is granted, there is already past information in the CIR database. The other group of loans, which we call "new", is from borrowers obtaining a loan for the first time.

\subsection{Descriptive statistics of the variables}

Descriptive information on the dependent and explanatory variables of the model of determinants of collateral is presented in Table 2 for "old" borrowers and in Table 3 for "new" borrowers.

The average size of the loan in the short-term group is half the size of that in the long-term group, as might be expected bearing in mind that short-term loans can be renewed over time. The mean value of the variable DEBT, which proxies the size of the borrower, is also twice as large in the column of long-term loans as it is in the column of short-term ones, meaning that long-term loans are more frequent among large firms (borrowers) than among small firms. The ratio between the average size of the loan among long-term loans and among short-term loans is the same for old and new borrowers, although the average size of the loans among the former is three times the size of the latter. This means that new borrowers start to borrow with relatively small loans, probably because the firms in the group are smaller on average than the older ones or, perhaps, because the bank that grants the loan is more cautious. Besides, the standard deviation shows that the size of the loan is more homogeneous in the short term than in the long term and much more so for new borrowers than for old ones.

Larger banks tend to make more long-term loans than smaller ones, as the average size of banks among the group of long-term loans is larger than the average size among the short-term ones. The average lender to new borrowers is smaller than the average lender to old borrowers, probably because, in general, small (new) firms tend to do more business with small banks while large firms do business with larger customers [Berger and Udell (1995), and Peek and Rosengren (1996)]. Commercial banks have a larger market share than savings

4. In this large database there is not a code for each loan. Thus, it becomes difficult to track a loan over time. Since we wish to know the precise year when the loan is granted, the sample finally selected has been limited to those loans for which it was possible to estimate the year when it was made. Loans maturing at less than one year have been excluded because it is impossible to know whether they are new or an extension of a loan made in the past. 
banks in short-term loans, among both old and new borrowers. The market share of savings banks is higher among new borrowers than among old ones.

The variables of relationship lending and the variable "AGE" AS A BORROWER show very similar values in the two columns of short- and long-term loans. These variables show substantial dispersion in the database, especially SCOPE and NUMBER OF LENDERS. The very high "maximum" values of these variables correspond to borrowers that do business in many provinces and have loan contracts with different banks in each province.

The proportion of borrowers that have a loan in default at the time they obtain a new loan, DEFAULT $T_{1, \mathrm{t}-1}$, is between 3 and $4 \%$ for old borrowers. Among those borrowers who are not in default when they obtain a short-term loan, 10\% have defaulted in the following year; this percentage is $7 \%$ for longer-term loans. Among new borrowers, $17 \%$ of those with a short-term loan will have defaulted in the following year after receiving the loan, while the percentage of defaulted loans in $t+1$ among the new borrowers with a long-term loan is $9 \%$. New borrowers with short-term loans have higher ex post credit risk than old borrowers with loans of the same maturity, although within the long-term loans the credit risks are the same for both groups ${ }^{5}$.

\subsection{Methodology}

The hypothesis about the determinants of the use of collateral in financial loans will be tested from the econometric estimation of a Probit model, which explains the dependent variable COLLATERAL as a function of the explanatory variables included in the model. The estimation will follow the "two-stage conditional maximum likelihood" (2SCML) procedure, developed by Rivers and Vuong (1988), to take into account the fact that the SIZE of the loan variable can be endogenous, i.e. jointly determined with the decision to ask for collateral.

Our model is composed of a structural equation of the Probit model that is of primary interest, and another reduced-form equation for the endogenous explanatory variable. The method works as follows: in the first step, the endogenous variable (log of the size of the loan) is written as a function of all of the exogenous explanatory variables. The model is estimated by ordinary least squares and its standardised residuals are considered as a new explanatory variable of the use of collateral. In the second stage the Probit model is estimated excluding the variables chosen as instruments of the SIZE variable and including the standardised error term obtained in the first step.

The instrument variable used is PRODUCT MARKET RISK, i.e. the proportion of bad loans to total loans in each of the eleven industries, lagged one period. This variable is highly statistically significant (with a negative coefficient) in the SIZE equation, while it is not correlated with the COLLATERAL variable. The proportion of non-performing loans in an economic sector provides an indication (inversely) of the opportunities for long-term investment as lenders are more willing to finance large projects in those sectors where firms have fewer difficulties repaying the loans. Also, lenders may take into account the economic risk of the loan in determining the interest rate but not in the decision whether to use collateral ${ }^{6}$.

Under this methodology, the parameters of the structural equation are not those obtained in the second-stage Probit model and have to be recovered with a simple

5. It may be of interest to compare some of these descriptive statistics with those presented by Berger and Udell (1995) for the US, and by Harhoff and Körting (1998) for Germany, keeping in mind that they work with credit-line data. In the US sample $53 \%$ of the loans have collateral while in the German sample the proportion is $62.4 \%$. In the US sample borrowers have been with the bank from which they obtain the line of credit $78 \%$ of the time since they first engaged in their activity (11.4 years of Duration and 14.1 years of Age), while for the German sample the percentage is $70 \%$ (12 and 17.5 years). In our sample the age of the borrowers is counted as from the time each one obtains the first loan (on appearing in the Credit Register for the first time), and the ratio of loyalty to the lender is $52 \%$ (2.95 and 5.66 years). Finally, almost 30\% of the firms in the German sample had been in financial distress during the past 5 years (3\% of our firms had a loan in default the year before they obtained a new one), while the average number of lenders they have relations with is 1.82 (3.94 in our sample). The German and US samples consider only small firms, while we have the population of Spanish firms as well as the whole population of financial loans.

6. We have performed the estimations using other instruments, such as $\mathrm{DEBT}_{1, \mathrm{t}-\mathrm{1}}$, and the main results do not change. 
transformation. Denoting by $\hat{\lambda}$ the estimated parameter for the variable "first-stage standardised error term", the original parameters for each of the other explanatory variables in the Probit model will be equal to the estimated one multiplied by the term $1 / \sqrt{1+\lambda^{2}}$.

This procedure also allows for the statistical testing of the hypothesis of endogeneity of the variable SIZE of the loan. To do so, it compares the log of the likelihood functions of the Probit model calculated with ( $\ln \mathrm{Lu}$ ) and without ( $\ln \mathrm{Lr}$ ) the standardised residuals obtained in the first stage. This is a widely used likelihood ratio test where the null hypothesis is that the variable is exogenous. The statistic $\mathrm{LR}=-2(\ln \mathrm{Lr}-\ln \mathrm{Lu})$ is distributed as a Chi-square with degrees of freedom equal to the number of endogenous variables in the Probit equation?

The estimation of the Probit model is repeated, following the procedure described above, for short-term and long-term loans, and for the two sub-samples of old and new borrowers.

The econometric procedure used to introduce borrowers' fixed effects into the empirical model is described in Greene (1993). The procedure is based on a conditional likelihood approach implemented in a Logit model where it is possible to find a sufficient statistic for the fixed effect, and after conditioning on it, the result obtained has similar properties to those obtained differentiating the data in conventional time and cross-section data panels. Therefore, the model to be estimated in this section is:

$$
\operatorname{Pr}\left(\text { Collateral }_{l t}=1 \mid x_{l 1}, \ldots, x_{l T}, \eta_{l}\right)=\frac{\exp \left(x_{l t} \beta+\eta_{l}\right)}{1+\exp \left(x_{l t} \beta+\eta_{l}\right)}
$$

where $\eta_{l}$ denotes the borrower-specific effect.

The Logit model with firm-specific effects works in samples where each individual has at least a zero (the borrower obtains a loan without collateral) and a one (the loan is with collateral). This substantially limits the sample of observations since only $25,199(72,370)$ borrowers and 126,377 $(357,527)$ loans satisfy this condition in the group of short- (long-) term loans. Therefore, the sample size in the group of old borrowers is one-quarter of the original one and the method can not be applied to new borrowers. Moreover, the new sample is biased towards larger firms, especially among the short-term loans, because the descriptive statistics (not reported) show that DEBT ${ }_{1, t-1}$ and SIZE of the loan are up to five times larger in the restricted sample than in the population of loans. In the reduced sample the proportion of short-term loans with collateral is $29.7 \%$, compared with $8.5 \%$ in the population, but in the group of long-term loans the proportion of loans with collateral is similar in the two samples ${ }^{8}$.

The model that tests the predictions on the amount of collateral, partial or total, will be a Multinomial Logit, where the dependent variable can be in one of three categories: no collateral, partial collateral (i.e. more than $50 \%$ of the loan is secured) and total collateral (i.e. $100 \%$ secured) ${ }^{9}$.

The variables DEBT, "AGE" AS BORROWER, DURATION, SCOPE, NUMBER OF LENDERS and SIZE OF THE LOAN will enter into the models in natural logs because we expect decreasing marginal effects on the impact of each of them in the probability of use of collateral in a particular loan.

7. Since, in our case, the number of endogenous variables is one, the LR test and the significance of the error term of the loan size are equivalent, so we will refer to both indistinctly.

8. The use of fixed borrowers' effects in this paper can also be justified because no information is available about age of the borrower and about accounting statements. Harhoff and Körting (1998) find that accounting data do not have explanatory power in the decision to use collateral in their sample of German firms.

9. When one or more of the explanatory variables are endogenous, as SIZE of the loan in our case, the most appropriate model to use is the Probit model. The use of the Multinomial Logit model in this case is taken as an approximation. 


\subsection{The Use of Collateral}

Tables 4 and 5 show the results from the estimation of the Probit model for old and new borrowers, respectively. Table 4 presents four estimations for each group of loans (long-term and short-term). The first two columns show the Probit estimations without fixed effects and the last two the results after borrower fixed effects are included in the Logit model. For the new borrowers (Table 5), a distinction is also made between short- and long-term loans but the control for fixed effects does not apply.

\subsubsection{OLD BORROWERS}

The Probit models, no fixed effects, are jointly statistically significant in the two groups of loans (short-term and long-term). The statistical tests confirm that SIZE of the loan is an endogenous variable ${ }^{10}$. The coefficients of variables DEBT, GEOGRAPHIC RISK and SCOPE are statistically significant only in the group of short-term loans; the coefficient of the variable NUMBER OF LENDERS is not significant in the group of short-term loans.

Overall, the pattern of results is quite similar in the two groups of loans and in line with the prior hypothesis. The use of collateral increases with the risk of the borrower, both ex ante (the coefficient of DEFAULT $T_{1,-1}$ is positive) and ex post (positive coefficient of DEFAULT $\left.T_{1, t+1}\right)$. However, the coefficient of the former variable is significantly larger than the coefficient of the latter ${ }^{11}$.

The likelihood of collateral is lower in more concentrated markets and is lower for borrowers that have longer relations with the lender that grants the loan. To work with a higher number of lenders reduces the likelihood of collateral in a statistically significant way in the group of long-term loans. More experienced and specialised banks tend to decrease the demand for collateral in their loan operations as the variables SIZE OF THE LENDER and SPECIALISATION have a coefficient with a negative sign. Savings banks ask, ceteris paribus, for more collateral than commercial banks. The downturn of the economy increases the likelihood of the use of collateral. In fact, a more thorough analysis shows that output growth has an asymmetric effect on the use of collateral since we observe a different impact depending on whether output growth is above or below its average (captured by the variable |GDP GROWTH - Average GDP GROWTH|). In this way, the likelihood of collateral diminishes proportionally more in the former situation than the increase in periods when actual growth is less than the long-term average. For instance, in the long term (short term), when GDP growth is below its average, the global effect is $-0.101(0.009)^{12}$ compared with the -0.114 $(-0.075)$ in upturns. In periods of tighter monetary policy or higher real interest rates, the use of collateral is less likely than in periods of loose monetary policy.

The likelihood ratio test confirms the statistical significance of the interactive variables DURATION and DEFAULT $T_{1, t-1}$ and DURATION and HERFIDAHL ${ }^{13}$. Their introduction into the model does not alter any of the previous results, although now the absolute values of the coefficients of the variables DEFAUT l,t-1 $_{1}$ and HERFINDAHL are split between the coefficients of the single and interactive variables. The coefficients of the two interactive

10. Not controlling for the endogeneity problem, the coefficient of the SIZE of the loan variable in the group of long-term loans would be higher than the value obtained with the correction, while in the group of short-term loans the correct parameter would have been underestimated.

11. The statistical tests of the null hypothesis that the coefficients of the variables DEFAULT $T_{1, t-1}$ and $D E F A U L T_{1, t-1}$ are equal is rejected at $p$-values of zero $\left[\chi^{2}(1)=825.22\right.$ for long-term and $\chi^{2}(1)=275.84$ for the short-term ones].

12. This sum of coefficients is statistically zero with a related $p$-value of $0.14\left[\chi^{2}(1)=2.16\right]$. This is always the case for short-term loans, for instance the $p$-value for the fixed-effects model is 0.24 and for new borrowers it increases to 0.26 .

13. For instance, for the Logit model with fixed effects the LR test follows a $\chi^{2}(2)$ and takes the value 58.14 for long-term loans, which is larger than the critical value of 5.99. For short-term loans this value is 36.04 . 
variables or cross-effects are both positive. Therefore, for the group of borrowers with a loan in default at the time they obtain a new loan, the effect of duration in the likelihood of obtaining a loan is positive when DEFAULT $T_{1, t-1}=1$ then the coefficient of duration equals $0.105(-0.174+0.279)$. Moreover, the effect of DURATION in the likelihood of collateral is lower, in absolute terms, in more concentrated credit markets than in less concentrated ones (the coefficient of DURATION is $-0.174+0.005 \cdot H E R F I D A H L)$.

The results from the Logit model with fixed effects are presented in the last two columns of the Table 4, for long-term loans, and Table 4 (Cont'd), for short-term loans. As might be expected, the comparison with the results from the Probit, no fixed effects, reveals that to control for borrowers unobserved heterogeneity affects mostly the coefficients of the variables that capture attributes of the borrower, such as relationship lending, amount of debt and years in the database. In the group of long-term loans the variables SCOPE and NUMBER OF LENDERS now have a negative and a positive sign (the opposite sign they have in the first two columns). DEBT now has a negative and significant coefficient and the coefficient of AGE is no longer statistically significant. For the rest of the variables the pattern of results remains unchanged, including those that capture the cross-effects.

In the group of short-term loans, the salient result is that fixed effects make the coefficients of DURATION and AGE AS BORROWER into non-statistically significant, while the coefficient of HERFINDAHL is now negative and significant. Further, SCOPE has a positive coefficient and NUMBER OF LENDERS a negative one, exactly the opposite signs of the coefficients of this variable in long term loans with fixed effects.

\subsubsection{NEW BORROWERS}

The pattern of results on the determinants of collateral for the sample of borrowers obtaining a loan for the first time, i.e. new borrowers, is quite similar to that observed among old borrowers for the shared variables (Table 5). The coefficient of DEFAULT $T_{1, t+1}$ is positive and significant for long-term and for short-term loans, although the coefficient of the variable is larger in the group of short-term loans than in the group of long-term loans. The comparison between the coefficients of the variable DEFAULT $T_{1, t+1}$ for old and new borrowers, Tables 4 and 5, indicates that these coefficients are lower in the group of new borrowers than in the group of old borrowers ${ }^{14}$.

The coefficient of HERFINDAHL is not significant in the sample of new borrowers, while macroeconomic conditions, GDP GROWTH and REAL INTEREST RATE, and the size of the loan affect the likelihood of collateral in a similar way they do for old borrowers.

\subsubsection{MARGINAL EFFECTS}

The statistical results on the determinants of collateral shown in Tables 4 and 5 are completed with the marginal effects of the changes in the explanatory variables (Table 6). The marginal effects are estimated from the Logit model with fixed effects and with coefficients of these fixed effects arbitrarily fixed at their zero values.

In the group of old borrowers who have a loan in default at the time of obtaining a new one, DEFAULT $T_{1,-1-1}=1$, increases the likelihood of use of collateral in the new loan by $13.9 \%$ if the loan is short-term, and $10.4 \%$ if it is long-term, compared with the likelihood of collateral if the new loan is for a borrower with no loans in default. For those old borrowers that default a loan one year after obtaining a new loan but did not have a loan in default in $t-1, D E F A U L T_{1, t+1}=1$, the likelihood of having to pledge collateral increases by $7.3 \%$ if the loan is short-term, and by $4.1 \%$ if the loan is long-term, compared with the likelihood of

14. For old borrowers the null hypothesis of equal coefficients for DEFAULT $T_{1,+1}$ in short- and long-term loans is rejected with a confidence level of $99 \%\left[\chi^{2}(1)=-29.64\right.$, $p$-value $\left.=0.00\right]$. For new borrowers this hypothesis can be rejected with a level of $95 \%\left[\chi^{2}(1)=-5.79, p\right.$-value $\left.=0.02\right]$. When the comparison is between new and old borrowers with long-term loans the confidence level is $99 \%\left[\chi^{2}(1)=7.84, p\right.$-value $\left.=0.01\right]$. Finally, the null hypothesis of equal coefficients for the variable in short-term loans to old and new borrowers can not be rejected $\left[\chi^{2}(1)=1.00\right.$, p-value $\left.=0.32\right]$. 
collateral in loans made to borrowers that do not default a loan in $t+1$. In the group of new borrowers the difference in the likelihood of collateral in a loan made to borrowers that default in $t+1$, compared with the likelihood of collateral in a loan made to borrowers that do not default is around $2.4 \%$ for both short-term and long-term loans, lower than the respective increases among old borrowers.

One point of increase in the concentration of the credit market, HERFINDAHL, lowers the likelihood of collateral in long-term (short-term) loans made to old borrowers by $0.16 \%(0.4 \%)$. Differences in concentration do not affect the likelihood of collateral in loans to new borrowers. On one hand, an additional year of relations with the bank, DURATION, decreases the likelihood of collateral by $0.25 \%$ in long-term loans made to old borrowers and leaves the likelihood of collateral unchanged if the loan is short-term. On the other, to increase the number of banks a borrower works with raises the likelihood of collateral by $0.56 \%$ if the new loan is long-term and reduces the likelihood around the same amount if the loan is short-term. If the loan is a long-term (short-term) one made by a commercial bank to an old borrower, the likelihood that the loan will have collateral is $8.7 \%(11.4 \%)$ lower than the likelihood of collateral if the same loan was made by a savings bank. Among new borrowers the percentage points by which the likelihood of collateral decreases are 3.3 and 1.4, respectively.

One additional percentage point of growth of GDP lowers the likelihood of collateral in long-term loans by around two percentage points. If the loan is made in a time period where GDP grows at a rate above the long-term trend, then loans made to old borrowers marginally reduce the probability of using collateral, additionally, by one percentage point in the case of long-term loans and 1.7 points if the loan is short-term. The reduction in the likelihood of collateral due to marginal increases in the real interest rate has a range of between $1.1 \%$ in short-term loans to old borrowers to $0.2 \%$ in long-term loans made to new borrowers.

\subsection{Amount of collateral}

The results of the Multinomial Logit model on the determinants of the amount of collateral (no collateral at all, partial collateral, and 100\% collateral) in loans to old borrowers, are presented in Table 7. The two columns of Table 7 show the estimated values, standard deviations and levels of significance for the differences between the coefficients of the Multinomial Logit that explains the likelihood of the collateral covering $100 \%$ of the face value of the loan, and the model of the likelihood of the loan being only partially covered by the collateral. A positive value indicates that an increase in the corresponding variable increases the likelihood of full collateral more than it does that of partial collateral. The estimated values for the differences in coefficients of the variable REAL INTEREST RATE are both positive, in short-term and in long-term loans, and statistically significant. For the SIZE variable of the loan, the other variable for which theoretical predictions exist, the estimated values of the differences between coefficients are both negative and also statistically significant.

\subsection{Robustness of the results}

The basic model (old borrowers and long-term loans) has been estimated with a different combination of explanatory variables to evaluate possible bias due to correlations among these variables and due to the fact that variables of relationship lending may not be totally exogenous. The results confirm the relevance of the control variables as determinants of the use of collateral since, in the case of long-term loans, the pseudo $\mathrm{R}^{2}$ of the model with control variables alone is 0.16 . They also show that the number of lenders is highly correlated with variables such as age as borrower and total debt at the time of the loan. The coefficients of these latter two variables are negative and significant when the number of lenders and fixed 
borrowers' effects are excluded from the model. When the number of lenders is one of the explanatory variables, the coefficient of debt is no longer significant and the coefficient of age as borrower decreases 74\% (in absolute terms). The rest of the results are robust to all different specifications.

Since the sample size for the estimation of the Logit model with fixed effects in the group of short-term loans is smaller and biased towards larger borrowers in comparison with the population of short-term loans, the Probit model with no fixed effects is estimated for this reduced sample to ensure that the differences in the results of the model with and without fixed effects are in fact due to the control for unobserved heterogeneity. The results obtained with the population of short-term loans and with the reduced sample, in both cases without fixed effects, are very similar, confirming that the key factor for the observed changes in the results of Table 4 (cont'd), with and without fixed effects, is due to this new control variable and not to differences in the sample of observations.

As indicated above, computation of the marginal effects in the Logit model with fixed effects has to be done assuming an arbitrary value for the intercept of the Logit function. The results of Table 6 are obtained assuming a value of zero for all borrowers. To ensure that the choice of the intercept does not affect the results of Table 6, the marginal effects have been re-estimated with other values of the intercept around those that give predictions close to the observed frequency of loans when the explanatory variables are set at their sample means. The choice of the value of the intercept does not significantly affect the values of the marginal effects. In addition, for short-term loans the marginal effects have been estimated again from the Probit model of the first column of Table 4 (cont'd) estimated without fixed effects and for the population of short-term loans. Except for relationship banking and for the risk variables, the marginal effects from the Probit (total population) and from the Logit model are quite similar.

In the case of the risk variables the results confirm and reinforce the conclusion that the marginal effects of the risk variables are smaller, in absolute and in relative terms, in the sample of new borrowers than in the sample of old borrowers. This has to do with the fact that the population of old and new borrowers taking out short-term loans are much more alike than the population of new borrowers and the restricted sample of borrowers of short-term loans. 
The evidence of this paper is in line with the findings of previous papers since our exogenous variables of ex ante and ex post credit risk of the borrower are both positively associated with the use of collateral. But the fact that the association between use of collateral and credit risk of the borrower varies in a predictable way, across situations that can be associated with more or less opportunities to use collateral as a signal of quality, suggests that the proper way to interpret the evidence is that in credit markets some loans are granted under conditions of observed risk and others under asymmetric information.

According to the empirical analysis presented in this paper (Table 6), for those borrowers that are known as low-quality borrowers when they apply for a new short-term loan (identified by the value of DEFAULT $T_{1,-1-1}=1$ ), the probability that the loan will be granted with collateral is 46.9\% (13.9/29.7) greater than if the same loan was granted to a borrower with no loan in default. If the loan is long-term the likelihood of collateral for those with loans in default is $20.6 \%(10.4 / 50.25)$ higher than for borrowers that pay their loans on time. Among those borrowers that have a loan in default a year after obtaining the current loan and that were current in their payments at the time the loan was made (identified by the variable DEFAULT $T_{1, t+1}$ ), the likelihood that the short-term loan they receive will be with collateral is $24.5 \%$ higher $(7.3 / 29.7)$ than the likelihood of collateral in short-term loans to borrowers that continue their loan payments on time. If the loan is long-term, the increase in the likelihood of the use of collateral is $8.2 \%$ (4.1/50.25). The same exercise in the group of firms that borrow a loan for the first time reveals that those borrowers that have a loan in default a year later have a $28.7 \%$ (3.9\%) higher probability of having used collateral in their first short-term (long-term) loan than a borrower that is not in default.

The highest increase in the probability of use of collateral is for borrowers whose low credit quality is public knowledge, and therefore there is no point in using collateral to signal quality. The second highest increase in probability corresponds to old borrowers that are not in default when they apply for and obtain a loan; for them the system will have a record of decisions and performance, for example accounting statements, that can be used to estimate their credit quality, but there are also opportunities to use collateral to signal high quality. Finally, the lowest increase in probability is for new borrowers, the group for which the signalling opportunities are higher. We interpret this pattern of results as evidence that, in the credit market, loans are made in a variety of information conditions and the results we observe in models of determinants of collateral such as that presented in this paper, are simply the net balance of loans in which collateral responds to situations of observed risk of the borrowers and loans in which collateral is used to signal quality.

Since the use of collateral is positively associated with risk ex post, a question of interest is to translate the ex ante observed presence of collateral in a loan into a conditioned probability of default. In other words, we are interested in the conditional probability that a borrower that obtains a loan with collateral today will have a loan in default in the next period. The conditional probabilities defined this way, together with the marginal probability of default from sample frequencies, are presented in Table 8. Higher differences between conditional and marginal probabilities imply higher information content of the signal use of collateral in the loan, as a predictor of credit risk. The results indicate that among short-term loans to old borrowers, to know that a loan is granted with collateral increases the likelihood that the borrower will default in $\mathrm{t}+1$ by $5.1 \%$, compared with the likelihood estimated from the sample frequency (15.03-9.96), namely a 51\% increase. If the loan is long-term the information of the signal is much lower since the conditional probability is only $10 \%$ higher than that obtained 
from the sample frequency. Among new borrowers the pattern of changes is maintained but the differences between conditional and marginal probabilities are lower than in the sample of old borrowers: $39 \%$ in short-term loans and $4 \%$ in long-term loans.

Therefore, even though the use of collateral is a signal of a low-quality borrower, the information content of the signal is substantially higher in short-term loans than in long-term ones and among older borrowers than among new borrowers. This evidence is consistent with previous evidence about the association between collateral and credit risk: collateral is less informative about the risk of the borrower in situations where the number of borrowers that use collateral as a signal of quality is expected to be higher.

We find that an increase in the duration of the relationship between the borrower and the lender and a larger number of operations between the two lower the likelihood of collateral in long-term loans. Also in long-term loans, the likelihood of collateral in a new loan is lower for borrowers that work with a smaller number of banks. However, duration does not have a significant effect on the use of collateral in short-term loans, while the number of relations with the lender increases the likelihood of collateral and working with more banks increases it. These results, obtained controlling for unobserved heterogeneity among borrowers (fixed effects), indicate that long-term loans are more likely to be conducted under relational lending while short-term ones are mainly transactional.

The paper also provides new results of interest for the literature on relationship lending. First, the economic significance of the effect of duration in the likelihood of use of collateral is substantially reduced when controls include borrowers' fixed effects, even for long-term loans. Without fixed effects a marginal increase in the duration of the relationship (one year more) lowers the likelihood of collateral by $2 \%$, while with fixed effects the figure is only $0.5 \%$. Second, longer duration only lowers the likelihood of collateral in the sample of borrowers that do not have a loan in default at the time of obtaining a new one. Therefore, the observed effect of duration in the likelihood of collateral in the whole sample indicates that longer relations benefit the lenders in the sense that they collect relevant information to refine the conditions of the initial loans, so that, over time, those borrowers that are classified as of low quality or high credit risk see their relation with the bank either terminated or continued but conditional on securing the loan with collateral. The fact that low-quality borrowers do not benefit at all from longer duration casts doubts on the trust argument as an explanation of why duration lowers the likelihood of collateral, and indicates that relationship lending benefits banks more than the firms that borrow from them. In this respect, the positive effect of the variable number of lenders on the likelihood of collateral among those loans made under relationship lending, long term, can be more properly interpreted considering that to have loans with several lenders is a signal of lower quality of the borrower.

Competition in the credit market affects the likelihood of collateral in loans, but the estimated economic significance of the effect is low in loans to old borrowers and null in loans to new borrowers. In Table 6 a marginal increase in the market concentration (one percentage point more) lowers the likelihood of collateral by $1.3 \%$ in short-term loans and by $0.3 \%$ in long-term loans. Nevertheless, the existing evidence would be consistent with theoretical results that predict more investment in production of information and softer loan terms in a less competitive credit market. But the paper goes a step further and compares the effect of the duration variable on the likelihood of collateral in credit markets of different concentration. The results show that the effect of duration on the likelihood of collateral is lower in more concentrated credit markets, which contradicts the hypothesis that less competition (more concentration) increases the value of specific borrower information. The evidence would be more in line with Boot and Thakor (2000), who predict more incentives for banks to offer differentiated services to their customers as competition increases. 
The characteristics of the lender are shown to have significant relevance for the likelihood of the use of collateral in loans. A short-term loan to old (new) borrowers is $38.4 \%$ (16.1\%) less likely to be with collateral if it is made by a commercial bank than if the lender is a savings bank. In long-term loans the reduction in the likelihood of collateral if the lender is a commercial bank is $17.3 \%$ (5.7\%). Larger banks are also less likely to ask for collateral in the loans they make than small banks. The difference is economically significant since a marginal increase in the size of the bank (one thousand euros more) reduces the likelihood of collateral by between $3.6 \%$ in short-term loans to old borrowers and $0.7 \%$ in long-term loans. Taking into account that specialisation of the lender in loans to business firms also lowers the likelihood of collateral, the evidence is interpreted in the sense that banks with higher expertise and with more resources to evaluate loan applications are less inclined to use collateral as a substitute for a thorough evaluation of the loan application ${ }^{15}$.

Macroeconomic conditions such as business cycle and monetary policy appear to have an economically significant effect on the use of collateral in business loan. One percentage point of increase in the GDP growth rate reduces the likelihood of collateral by around $4 \%$ after considering all other microeconomic variables. In short-term loans marginal increases in the upward deviation in the growth rate of the economy with respect to the growth trend reduce the likelihood of collateral by $5 \%$ more if the loan is long-term. Among short-term loans to new borrowers, a marginal increase in the real interest rate of the economy (one percentage point more) lowers the likelihood of collateral in new loans by $5.5 \%$. (3.8\% if the loan is to old borrowers).

From other control variables the evidence indicates that larger borrowers are less likely to place collateral in their loans. The variable DEBT is used as a proxy of size and has a negative and significant coefficient, although the marginal effect is very low. The likelihood of collateral increases with the size of the loan; the economic significance of this increase is particularly high in the group of short-term loans to new borrowers where a marginal increase in the size of the loans implies a $1 \%$ increase in the likelihood of collateral.

Finally, the tests of the predictions by Boot, Thakor, and Udell (1991) that the amount of collateral pledged in a particular loan will increase if the loan is made in a period of higher real interest rates, and will be lower in larger than in smaller loans, confirm the theoretical results. This evidence could confirm that moral hazard problems condition the use of collateral in loans. The model recommends increasing the amount of collateral, instead of charging higher interest on the loan, in situations where to increase the interest on the loan with a risk premium when the risk-free interest rate is already high would worsen the moral hazard situation created after the loan is received.

15. Berger (2004) interprets the fact that larger banks tend to lend more often without collateral as evidence that they specialise in transactional lending to relatively safe and transparent firms. 


\section{Conclusions}

This paper presents a comprehensive empirical analysis of the determinants of the use of collateral in financial loans summarised in six main hypotheses and the exploration of other empirical determinants introduced into the model as control variables. The tests of the hypothesis show that most of the loans are made under observed risk of the borrower [Berger and Udell (1991)], so the likelihood of collateral increases for low quality borrowers even when this quality is revealed after the loan is made (and borrowers had the opportunity to use collateral to signal high quality). However, the evidence indicates that the likelihood of collateral among those that reveal ex post as low quality is lower in the group of inexperienced, young borrowers, those with more opportunities to get a loan under private information, than among old and experienced ones. This evidence provides preliminary empirical support of the theories that explain collateral as a solution to adverse selection problems [Bester (1985), and Besanko and Thakor (1987a)]. Therefore the final conclusion has to be that the fact that collateral increases with credit risk of the borrower is a net effect of higher proportion of loans made under observed risk than under private information.

We also find support for the hypothesis of better sorting of borrowers in low and high quality as explanation of the negative effect of duration of the borrower-lender relationship in the likelihood of using collateral [Berger and Udell (1995)], instead of the trust explanation given by Boot and Thakor (1994). Moreover, the use of collateral is less likely in more concentrated credit markets but concentration seems to lower the incentives to invest in information, in line with Boot and Thakor (2000) who predict higher investments in relationship specific information and assets as competition in the credit market increases. Finally, evidence is provided in support of those who explain the use of collateral as an alternative to thorough screening of loan projects [Manove and Padilla (1999 and 2001)], and of those that predict that more collateral is an alternative to higher interest rate of the loan under moral hazard [Boot, and Thakor, and Udell (1991)].

The empirical analysis is performed with a unique database, the Credit Register of the Spanish central bank, which contains the population of new loans made every year in the period 1984-2002. Within a selected sample of loans it has been possible to examine the determinants of collateral controlling for borrower fixed effects (i.e. applying panel data econometric techniques). Nevertheless, the database has some obvious limitations: it does not contain information on the interest rate or the purpose of the loan; there is no information on the nature of collateral (i.e. if it is internal or nor) or the exact amount of collateral (i.e. collateral is not a continuous variable); and, finally, it does not contain some relevant characteristics of the firms (i.e. financial variables). This lack of information limits the scope of the tests that we can perform regarding collateral although it should not affect the results obtained in the paper.

The empirical analysis of collateral presented in this paper opens new lines of research into the determinants of collateral to explain the regularities observed in the effect of macroeconomic conditions on the decision to use collateral. We find that a decrease in the GDP growth rate increases the likelihood of loans being made with collateral and, also, that this effect is asymmetric in the sense that the likelihood of collateral diminishes proportionally more when the economy is above its long-term trend than it increases when the actual growth is less than its average. The effect of the business cycle on loan conditions seems to be stronger in loans to new borrowers entering the system for the first time, than in loans to established borrowers, while general economic conditions tend to trigger earlier responses in long-term loans than in short-term ones. The real interest rate of the economy 
affects the decision to use collateral in a different way than the decision over its amount, with a negative effect arising in the first case and a positive one in the second.

The findings of the paper have some relevant implications. Credit markets seem to function in a different way in loans with different maturities, short and long-term, and among borrowers with different experience in the loan market (old and new borrowers). Research on the determinants of loan terms and conditions should focus on segments of the credit markets other than small or large firms, as has been the common practice in the past. Large databases will be more suited for this new line of research, and in particular data that cover several time-periods, since evidence shows that the business cycle and other general economic conditions, such as the interest rate of the economy, play a role in determining terms of credit such as the use and amount of collateral, even after controlling for microeconomic variables.

Banking regulators often look for signals that are predictors of risk and other sources of financial instability. The presence of collateral in loans may be one of these signals and, in fact, more use of collateral in loans will indicate that loans go to borrowers of low quality and higher risk. Collateral is a way to curve down the risk of the loan operation taking into account the influence of the characteristics and behaviour of the borrower in such a risk. But, in keeping with the general observation above that the credit markets appear highly segmented, the information content of the signal "use of collateral in the loan" is substantially different among new borrowers than among old borrowers, and among short-term loans (with 10\% of collateralised loans in our database) than among long-term loans (where 50\% of the loans have collateral).

Basel II will create incentives to lenders to invest in a more thorough analysis of the credit risk of borrowers. Evidence seems to indicate that lenders differ in their expertise and capabilities to evaluate the risk of the loans they grant, something that may not be so relevant at a time when the benefits of investing to gain such expertise and capabilities are low but that may be more important in the future under the new regulation of capital. One important research topic that has emerged from our analysis is to investigate whether the new regulations in the capital requirements of banks may change the way banks view the use of collateral in loan operations. 
BERGER, A. N. (2004). Potential competitive effects of Basel II on banks in SME credit markets in the United States, mimeo.

BERGER, A. N., and G. F. UDELL (1990). "Collateral, loan quality, and bank risk", Journal of Monetary Economics, 25, pp. 21-24.

— (1995). "Relationship lending and lines of credit in small firm finance", Journal of Business, 68, pp. 351-382.

- (2002). "Small business credit availability and relationship lending: the importance of bank organization structure", Economic Journal, 112, pp. 32-53.

BESANKO, D., and A. V. THAKOR (1987a). "Collateral and rationing: sorting equilibria in monopolistic and competitive credit markets", International Economic Review, 28, pp. 671-689.

- (1987b). "Competitive equilibria in the credit market under asymmetric information", Journal of Economic Theory, 42, pp. 167-182.

BESTER, H. (1985). "Screening vs. rationing in credit markets with imperfect information", American Economic Review 75, pp. $850-855$.

BОOT, A. W. A. (2000). "Relationship banking: what do we know?", Journal of Financial Intermediation, 9, pp. 7-25.

BOOT, A. W. A, and A. V. THAKOR (1994). "Moral hazard and secured lending in an infinitely repeated credit market Game", International Economic Review, 35, pp. 899-992.

— (2000). "Can relationship banking survive competition?", The Journal of Finance, 55, pp. 679-713.

BOOT, A. W. A., A. V. THAKOR, and G. F. UDELL (1991). "Secured lending and default risk: equilibrium analysis, policy implications and empirical results", The Economic Journal, 101, pp. 458-472.

CHAN, Y. S., and G. KANATAS (1985). "Asymmetric valuation and the role of collateral in loan agreements", Journal of Money, Credit and Banking, 17, pp. 85-95.

CHAN, Y. S., S. I. GREENBAUM, and A. V. THAKOR (1986). "Information reusability, competition and bank asset quality", Journal of Banking and Finance, 10, pp. 255-276.

DEGRYSE, H., and P. VAN CAYSEELE (2000). "Relationship lending within a bank-based system: evidence from european small business data", Journal of Financial Intermediation, 9, pp. 90-109.

DIAMOND (1991). "Monitoring and reputation: the choice between bank loans and privately placed debt", Journal of Political Economy, 99, pp. 689-721.

FARINHA, L., and J. A. C. SANTOS (2002). "Switching from single to multiple bank lending relationships: determinants and implications", Journal of Financial Intermediation, 11, pp. 124-151.

GREENBAUM, S., G. KANATAS, and I. Venezia (1989). "Equilibrium loan pricing under the bank-client relationship", Journal of Banking and Finance, 13, pp. 221-235

GREENE, W. H. (1993). Econometric Analysis, Macmillan.

HARHOF, D., and KÖRTING (1998). "Lending relationships in germany-empirical evidence from survey data", Journal of Banking and Finance, 22, pp. 1317-1353.

JIMÉNEZ, G., and J. SAURINA (2004). "Collateral, type of lender and relationship banking as determinants of credit risk", Journal of Banking and Finance, 28, pp. 2191-2212.

JOHN, K., A. W. LYNCH, and M. PURI (2003). "Credit ratings, collateral and loan characteristics: implications for yield", Journal of Business, 76, pp. 371-409.

MANOVE, M., and A. J. PADILLA (1999). "Banking (conservatively) with optimists", RAND Journal of Economics, 30, pp. 324-350.

- (2001). "Collateral versus project screening: a model of lazy banks", RAND Journal of Economics, 32, pp. 726-744.

PEEK, J., and E. S. ROSENGREN (1996). "Small business credit availability: how important is size of lender?" in Financial system design: the case of universal bankin, A. Saunders and I. Walter (eds.), Irwin, Burr Ridge, pp. 628-655.

PETERSEN, M. E., and R. G. RAJAN (1994). "The benefits of firm-creditor relationships: evidence from small business data", The Journal of Finance, 49, pp. 3-37.

— (1995). "The effect of credit market competition on lending relationships", Quarterly Journal of Economics, 110, pp. 407-444.

RAJAN, R. G. (1992). "Insiders and outsiders: the choice between informed and arm's-length debt", The Journal of Finance, 47, pp. 1367-1399.

RIVERS, D., and Q. H. Vuong (1988). "Limited information estimators and exogeneity test for simultaneous Probit models", Journal of Econometrics, 39, pp. 347-366.

SHARPE, S. A. (1990). "Asymmetric information, bank lending, and implicit contracts: a stylised model of customer relationships", The Journal of Finance, 45, pp. 1069-1087.

SMITH, C., and J. WARNER (1979). "On financial contracting: an analysis of bond covenants", Journal of Financial Economics, 7, pp. 117-161.

STULZ, R., and H. JOHNSON(1985). "An analysis of secured debt", Journal of Financial Economics, 14, pp. 501-522.

THAKOR, A. (1996). "Capital requirements, monetary policy and aggregate bank lending: theory and empirical evidence", The Journal of Finance, 51, pp. 279-324. 
Table 1

\section{Definition of the variables}

List of variables used in the empirical analysis and their respective definition.

Variables

Definition

\begin{tabular}{|c|c|}
\hline \multicolumn{2}{|l|}{ Borrower's Risk } \\
\hline Default $_{t-1}$ & 1 if the borrower has defaulted on a loan at any time in previous year, 0 otherwise \\
\hline Default ${ }_{t+1}$ & 1 if the loan default is in the first year but not in $t-1,0$ otherwise \\
\hline \multicolumn{2}{|l|}{ Competition } \\
\hline Herfindahl ${ }_{t}$ & Sum of squared market shares of the lenders in the loan market of the province (\%) \\
\hline \multicolumn{2}{|l|}{ Relationship lending } \\
\hline Duration $_{\mathrm{t}-1}$ & Number of years since the borrower had the first loan with the lender at the beginning of the period \\
\hline Scope $_{t-1}$ & Number of loan operations with the lender at the beginning of the period \\
\hline Number of lenders $t_{t-1}$ & Number of lenders with which the borrower has relations at the beginning of the period \\
\hline \multicolumn{2}{|c|}{ Experience and preferences of lender } \\
\hline Size of the lender ${ }_{t}$ & Assets of the lender relative to the total assets of the system (\%) \\
\hline Bank & 1 if the lender is a commercial bank, 0 otherwise \\
\hline Specialisation $_{\mathrm{t}}$ & Percentage of loans to firms by the lender (\%) \\
\hline \multicolumn{2}{|l|}{$\begin{array}{l}\text { Control Variables } \\
\quad \text { Economic conditions }\end{array}$} \\
\hline 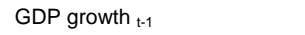 & Growth of the GDP in the year prior to which the loan is made (\%) \\
\hline |GDPG $_{\mathrm{t}-1}-$ Average GDPG $_{\mathrm{t}-1} \mid$ & Absolute difference between GDP growth in t-1and average GDP growth in t-1 in the sample (\%) \\
\hline Real interest rate $_{\mathrm{t}}$ & 3-month interbank interest rate minus rate of change in $\mathrm{CPI}$ in the year of the loan (\%) \\
\hline Geographic risk $t-1$ & Proportion of bad loans in the province of the borrower at the beginning of the period (\%) \\
\hline Product Market risk $\mathrm{t}-1_{1}$ & Proportion of bad loans in the economic sector of the borrower at the beginning of the period (\%) \\
\hline \multicolumn{2}{|l|}{ Firm's characteristics } \\
\hline Debt $_{t-1}$ & Total amount of debt of the borrower at the beginning of the period (in thousands of euro) \\
\hline "Age" as Borrower ${ }_{\mathrm{t}-1}$ & Number of years since the first recorded loan to the borrower at the beginning of the period \\
\hline Province & Dummy variable for the $(50)$ provinces of geographic markets \\
\hline Industry & Dummy variable for the (11) economic sectors of the lender \\
\hline \multicolumn{2}{|l|}{ Loan's characteristics } \\
\hline Size of the loan & Amount of the loan operation (in thousands of euro) \\
\hline \multicolumn{2}{|l|}{ Dependent variables } \\
\hline Collateral & 1 if the loan has collateral, 0 otherwise \\
\hline \multirow[t]{3}{*}{ Amount of collateral } & 0 if the loan does not have collateral \\
\hline & 1if the loan is partially secured \\
\hline & 2 if the loan is fully secured \\
\hline
\end{tabular}

Note: Debt and Size of the loan at constant prices of 2002. 
Table 2

\section{Descriptive statistics: Old borrowers}

Summary statistics of the variables used in the analysis for the group of Old borrowers. Time period 1984 to 2002. For the definition of the variables, see Table 1.

Variables

Mean

\begin{tabular}{|c|c|c|c|c|c|c|c|c|}
\hline & & & & \\
\hline & Long term & Short term & Long term & Short term & Long term & Short term & Long term & Short term \\
\hline \multicolumn{9}{|l|}{ Borrower's Risk } \\
\hline Default $t_{t-1}$ & 0.04 & 0.03 & 0.20 & 0.16 & 0.00 & 0.00 & 1.00 & 1.00 \\
\hline Default $t_{t+1}$ & 0.07 & 0.10 & 0.26 & 0.30 & 0.00 & 0.00 & 1.00 & 1.00 \\
\hline \multicolumn{9}{|l|}{ Competition } \\
\hline Herfindahl ${ }_{\mathrm{t}}(\%)$ & 6.87 & 6.48 & 2.67 & 2.64 & 2.52 & 2.52 & 42.48 & 42.48 \\
\hline \multicolumn{9}{|c|}{ Experience and preferences of lender } \\
\hline Size of the lender ${ }_{t}(\%)$ & 3.72 & 3.27 & 3.83 & 3.27 & 0.00 & 0.00 & 15.36 & 15.36 \\
\hline Bank & 0.51 & 0.62 & 0.50 & 0.49 & 0.00 & 0.00 & 1.00 & 1.00 \\
\hline Specialisation $_{\mathrm{t}}(\%)$ & 57.14 & 61.07 & 16.18 & 17.12 & 0.34 & 1.12 & 100.00 & 100.00 \\
\hline \multicolumn{9}{|l|}{ Relationship lending } \\
\hline Duration $_{\mathrm{t}-1}$ & 2.95 & 2.89 & 3.40 & 3.24 & 0.00 & 0.00 & 18.00 & 18.00 \\
\hline Scope $_{t-1}$ & 1.46 & 1.54 & 1.97 & 1.65 & 0.00 & 0.00 & 637.00 & 371.00 \\
\hline Number of lenders $t_{t-1}$ & 3.94 & 3.93 & 9.71 & 6.69 & 0.00 & 0.00 & 184.00 & 184.00 \\
\hline \multicolumn{9}{|l|}{ Control Variables } \\
\hline \multicolumn{9}{|l|}{ Economic conditions } \\
\hline GDP growth $\mathrm{t-1}(\%)$ & 3.13 & 3.13 & 1.56 & 1.56 & -1.03 & -1.03 & 5.55 & 5.55 \\
\hline $\mid G^{\prime} D P G_{t-1}$ - Average GDPG $_{t-1} \mid(\%)$ & 1.24 & 1.24 & 0.95 & 0.95 & 0.13 & 0.13 & 4.16 & 4.16 \\
\hline Real interest rate ${ }_{\mathrm{t}}(\%)$ & 4.19 & 4.19 & 3.22 & 3.22 & -1.01 & -1.01 & 9.36 & 9.36 \\
\hline Geographic risk $t_{t-1}(\%)$ & 5.77 & 5.77 & 4.32 & 4.32 & 0.48 & 0.48 & 28.34 & 28.34 \\
\hline Product Market risk $_{\mathrm{t}-1}(\%)$ & 4.38 & 4.38 & 3.47 & 3.47 & 0.05 & 0.05 & 14.86 & 14.86 \\
\hline \multicolumn{9}{|l|}{ Firm's characteristics } \\
\hline Debt $_{t-1}$ & 15.97 & 7.83 & 193.18 & 127.23 & 0.00 & 0.00 & 6234.27 & 6234.27 \\
\hline "Age" as Borrower ${ }_{\mathrm{t}-1}$ & 5.66 & 5.38 & 4.28 & 4.16 & 1.00 & 1.00 & 18.00 & 18.00 \\
\hline \multicolumn{9}{|l|}{ Loan's characteristics } \\
\hline Size of the loan & 0.59 & 0.29 & 7.04 & 4.71 & 0.01 & 0.01 & 2810.56 & 2937.16 \\
\hline \multicolumn{9}{|l|}{ Dependent variable } \\
\hline Collateral & 0.53 & 0.08 & 0.50 & 0.28 & 0.00 & 0.00 & 1.00 & 1.00 \\
\hline$\%$ fully collateralised & 95.02 & 88.19 & & & & & & \\
\hline
\end{tabular}

Note: The variables Debt and Size of the loan are in millions of euro. 
Table 3

Descriptive statistics: New borrowers

Summary statistics of the variables used in the analysis for the group of New borrowers. Time period 1984 to 2002. For the definition of the variables, see Table 1.

Variables

Mean

\begin{tabular}{|c|c|c|c|c|c|c|c|c|}
\hline & Long term & Short term & Long term & Short term & Long term & Short term & Long term & Short term \\
\hline \multicolumn{9}{|l|}{ Borrower's Risk } \\
\hline Default $_{t+1}$ & 0.09 & 0.17 & 0.29 & 0.38 & 0.00 & 0.00 & 1.00 & 1.00 \\
\hline \multicolumn{9}{|l|}{ Competition } \\
\hline Herfindhal $_{\mathrm{t}}(\%)$ & 6.75 & 6.36 & 2.70 & 2.63 & 2.52 & 2.52 & 42.48 & 42.48 \\
\hline \multicolumn{9}{|c|}{ Experience and preferences of lender } \\
\hline Size of the lender ${ }_{t}(\%)$ & 3.36 & 2.91 & 3.46 & 2.99 & 0.00 & 0.00 & 15.36 & 15.36 \\
\hline Bank & 0.42 & 0.52 & 0.49 & 0.50 & 0.00 & 0.00 & 1.00 & 1.00 \\
\hline Specialisation ${ }_{\mathrm{t}}(\%)$ & 54.69 & 58.24 & 15.80 & 17.73 & 1.12 & 1.12 & 100.00 & 100.00 \\
\hline \multicolumn{9}{|l|}{ Control Variables } \\
\hline \multicolumn{9}{|l|}{ Economic conditions } \\
\hline GDP growth $_{\mathrm{t}-1}(\%)$ & 3.13 & 3.13 & 1.56 & 1.56 & -1.03 & -1.03 & 5.55 & 5.55 \\
\hline $\mid$ GDPG $_{\mathrm{t}-1}-$ Average GDPG $_{\mathrm{t}-1} \mid(\%)$ & 1.24 & 1.24 & 0.95 & 0.95 & 0.13 & 0.13 & 4.16 & 4.16 \\
\hline Real interest rate ${ }_{\mathrm{t}}(\%)$ & 4.19 & 4.19 & 3.22 & 3.22 & -1.01 & -1.01 & 9.36 & 9.36 \\
\hline Geographic risk ${ }_{t-1}(\%)$ & 5.77 & 5.77 & 4.32 & 4.32 & 0.48 & 0.48 & 28.34 & 28.34 \\
\hline Product Market risk $\mathrm{t}_{\mathrm{t}-1}(\%)$ & 4.38 & 4.38 & 3.47 & 3.47 & 0.05 & 0.05 & 14.86 & 14.86 \\
\hline \multicolumn{9}{|l|}{ Loan's characteristics } \\
\hline Size of the loan & 0.21 & 0.10 & 2.95 & 0.72 & 0.01 & 0.01 & 1341.85 & 67.35 \\
\hline \multicolumn{9}{|l|}{ Dependent variable } \\
\hline Collateral & 0.58 & 0.09 & 0.49 & 0.28 & 0.00 & 0.00 & 1.00 & 1.00 \\
\hline$\%$ fully collateralised & 96.47 & 90.93 & & & & & & \\
\hline
\end{tabular}

Note: The variables Debt and Size of the loan are in millions of euro. 
Table 4

\section{Determinants of collateral: Old Borrowers and Long-Term Loans}

Results of the estimation of the determinants of the probability that a loan in year $t$ will have collateral given the Risk of the Borrower, the Concentration in the Geographic Market, the Relationship between the lender and the borrower, and the Macroeconomic environment, the Characteristics of the lender and the Size of the loan as control variables for the group of Old Borrowers and Long-Term Loans. Probit model estimated by 2SCML. For the definition of the variables, see Table 1.

\begin{tabular}{|c|c|c|c|c|c|c|c|c|}
\hline \multirow[b]{2}{*}{ Variable } & \multicolumn{8}{|c|}{ Old Borrowers. Long term } \\
\hline & & & \multicolumn{2}{|c|}{ Cross-Effects } & \multicolumn{2}{|c|}{ Fixed Effects } & \multicolumn{2}{|c|}{ Fixed Effs. Cross-Effs. } \\
\hline Dependent Variable & \multicolumn{2}{|c|}{ Collateral $(1 / 0)$} & \multicolumn{2}{|c|}{ Collateral $(1 / 0)$} & \multicolumn{2}{|c|}{ Collateral $(1 / 0)$} & \multicolumn{2}{|c|}{ Collateral (1/0) } \\
\hline \multirow[t]{2}{*}{ Estimation } & \multicolumn{2}{|c|}{$2 \mathrm{SCML}$} & \multicolumn{2}{|c|}{$2 \mathrm{SCML}$} & \multicolumn{2}{|c|}{ Logit with fixed effects } & \multicolumn{2}{|c|}{ Logit with fixed effects } \\
\hline & Coefficient & $S D$ & Coefficient & $S D$ & Coefficient & $S D$ & Coefficient & $S D$ \\
\hline Constant & 0.119 & 0.202 & 0.150 & 0.200 & -- & -- & -- & -- \\
\hline \multicolumn{9}{|l|}{ Borrower's Risk } \\
\hline Default $\mathrm{t}-1$ & 0.703 & $0.025 * * *$ & 0.361 & $0.034 * * *$ & 0.580 & $0.026 * \star *$ & 0.314 & $0.046 * * *$ \\
\hline Default $_{t+1}$ & 0.219 & $0.018 * \star *$ & 0.219 & $0.018 * \star *$ & 0.232 & $0.022 * \star \star *$ & 0.233 & $0.022 * \star \star$ \\
\hline \multicolumn{9}{|l|}{ Competition } \\
\hline Herfindahl $_{\mathrm{t}}$ & -0.010 & $0.002 * * *$ & -0.015 & $0.002 * * *$ & -0.009 & 0.003 ** & -0.016 & $0.004 * * *$ \\
\hline \multicolumn{9}{|l|}{ Experience and prefs. of lender } \\
\hline Size of the lender ${ }_{t}$ & -0.019 & $0.001 * * *$ & -0.019 & $0.001 * * *$ & -0.036 & $0.001 * * *$ & -0.036 & $0.001 * * *$ \\
\hline Bank & -0.242 & $0.014 * * *$ & -0.242 & $0.014 * * *$ & -0.486 & $0.015 * * *$ & -0.485 & $0.015 * * \star$ \\
\hline Specialization $_{\mathrm{t}}$ & -0.014 & $0.001 * \star *$ & -0.014 & $0.001 * \star *$ & -0.010 & $0.000 * \star \star$ & -0.010 & $0.000 * \star \star$ \\
\hline \multicolumn{9}{|l|}{ Relationship lending } \\
\hline $\log \left(\right.$ Duration $\left._{t-1}\right)$ & -0.132 & $0.005 * \star \star$ & -0.174 & $0.009 * \star \star$ & -0.041 & $0.008 * \star \star$ & -0.092 & $0.017 * * *$ \\
\hline $\log \left(\right.$ Scope $\left._{t-1}\right)$ & 0.015 & 0.010 & 0.018 & $0.010 *$ & -0.095 & $0.011^{* * *}$ & -0.093 & $0.011 * * *$ \\
\hline $\log \left(\right.$ Number of lenders $\left.t_{t-1}\right)$ & -0.482 & $0.059 * * *$ & -0.478 & $0.059 * * *$ & 0.123 & $0.018 * * *$ & 0.129 & $0.018 * * *$ \\
\hline \multicolumn{9}{|l|}{$\begin{array}{l}\text { Control Variables } \\
\text { Economic conditions }\end{array}$} \\
\hline GDP growth $_{\mathrm{t}-1}$ & -0.107 & $0.002 * \star *$ & -0.108 & $0.002 * \star *$ & -0.101 & $0.004 * * \star$ & -0.101 & $0.004 * * *$ \\
\hline $\mid$ GDPG $_{\mathrm{t}-1}-$ Average GDPG $_{\mathrm{t}-1} \mid$ & -0.007 & $0.003 * *$ & -0.007 & $0.003 * *$ & -0.058 & $0.006 * * *$ & -0.058 & $0.006 * * *$ \\
\hline Real interest rate $_{\mathrm{t}}$ & -0.014 & $0.001 * \star *$ & -0.014 & $0.001 * * \star$ & -0.037 & $0.003 * * *$ & -0.037 & $0.003 * * *$ \\
\hline Geographic risk t-1 & -0.001 & 0.001 & -0.001 & 0.001 & 0.010 & $0.002 * \star \star$ & 0.011 & $0.002 * * *$ \\
\hline \multicolumn{9}{|l|}{ Firm's characteristics } \\
\hline $\log \left(D_{e b t}-1\right)$ & 0.025 & 0.039 & 0.024 & 0.039 & -0.076 & $0.006 * * \star$ & -0.076 & $0.006 * \star \star$ \\
\hline $\log \left(\right.$ "Age" as Borrower ${ }_{\mathrm{t}-1}$ ) & -0.015 & $0.006 * *$ & -0.015 & 0.006 ** & 0.005 & 0.010 & 0.007 & 0.010 \\
\hline Loan's characteristics & & & & & & & & \\
\hline $\log ($ Size of the loan) & 0.315 & $0.073 * * *$ & 0.317 & $0.073 * * *$ & 0.776 & $0.005 * * *$ & 0.776 & $0.005 * * *$ \\
\hline Error log(Size of the loan) $(\lambda)$ & 0.264 & $0.073 * * *$ & 0.311 & $0.087 * \star *$ & -- & -- & -- & -- \\
\hline \multicolumn{9}{|l|}{ Cross-effects } \\
\hline Default $_{\mathrm{t}-1}{ }^{*} \log \left(\right.$ Duration $\left.\left._{\mathrm{t}-1}\right)\right)$ & -- & -- & 0.279 & $0.017 * * *$ & -- & -- & 0.199 & 0.028 *** \\
\hline Herfindahl ${ }_{t}^{*} \log \left(\right.$ Duration $\left._{\mathrm{t}-1}\right)$ & -- & -- & 0.005 & $0.001 * * *$ & -- & -- & 0.006 & $0.002 * * *$ \\
\hline No. Observations & 823,340 & & 823,340 & & 357,527 & & 357,527 & \\
\hline$\%$ collateralised & 53.22 & & 53.22 & & 50.25 & & 50.25 & \\
\hline $\log L$ & $-467,443$ & & $-467,300$ & & $-120,678$ & & $-120,649$ & \\
\hline$\chi^{2}$ covariates & 147,630 & & 147,728 & & 46,165 & & 46,223 & \\
\hline Pseudo $\mathrm{R}^{2}$ & 0.179 & & 0.179 & & 0.161 & & 0.161 & \\
\hline$\left(1+\lambda^{2}\right)^{-1 / 2}$ & 0.967 & & 0.955 & & -- & & -- & \\
\hline
\end{tabular}

Notes:

a. Each regression also includes 49 regional dummies and 10 industry dummies. The estimations obtained using the $2 \mathrm{SCML}$ methodology, have to be multiplied by the term $1 / \sqrt{1+\hat{\lambda}^{2}}$ to recover the original parameters. To allow the comparison between the logistic model and the 2SCML, the parameters of the latter have been multiplied by 1.6 following Greene (1993).

b. $* * *$ associated variable significant at $1 \%, * *$ at $5 \%$, and $*$ at $10 \%$. 
Table 4 (Cont'd)

\section{Determinants of collateral: Old Borrowers and Short-Term Loans}

Results of the estimation of the determinants of the probability that a loan in year $t$ will have collateral given the Risk of the Borrower, the Concentration in the Geographic Market, the Relationship between the lender and the borrower, and the Macroeconomic environment, the Characteristics of the lender and the Size of the loan as control variables, for the group of Old Borrowers and Short Term Loans. Probit model estimated by 2SCML. For the definition of the variables, see Table 1.

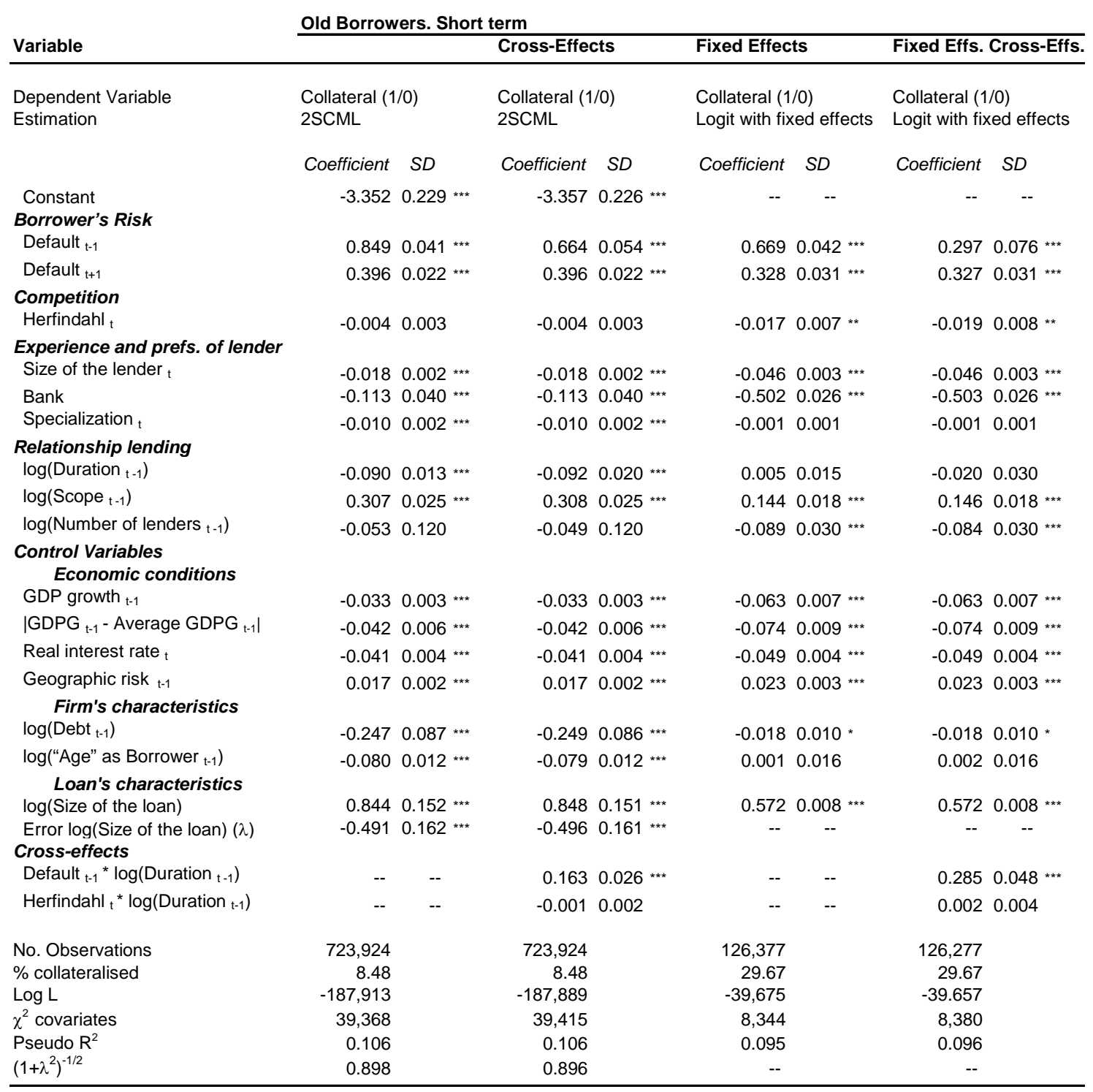

Notes:

a. Each regression also includes 49 regional dummies and 10 industry dummies. The estimations obtained using the 2SCML methodology have to be multiplied by the term $1 \sqrt{1+\hat{\lambda}^{2}}$ to recover the original parameters. To allow the comparison between the logistic model and the $2 \mathrm{SCML}$ the parameters of the latter have been multiplied by 1.6 following Greene (1993).

b. $* * *$ associated variable significant at $1 \%, * *$ at $5 \%$, and $*$ at $10 \%$. 
Table 5

\section{Determinants of collateral: New Borrowers}

Results of the estimation of the determinants of the probability that a loan in year $t$ will have collateral given the Risk of the Borrower, the Concentration in the Geographic Market, and the Macroeconomic environment and the Size of the loan as control variables, for the group of New Borrowers. Probit model estimated by $2 \mathrm{SCML}$. For the definition of the variables, see Table 1.

\begin{tabular}{|c|c|c|c|c|}
\hline \multirow[b]{2}{*}{ Variable } & \multicolumn{4}{|c|}{ New Borrowers } \\
\hline & \multicolumn{2}{|c|}{ Long term } & \multicolumn{2}{|l|}{ Short term } \\
\hline Dependent Variable & \multicolumn{2}{|c|}{ Collateral $(1 / 0)$} & \multicolumn{2}{|c|}{ Collateral $(1 / 0)$} \\
\hline \multirow[t]{2}{*}{ Estimation } & \multicolumn{2}{|c|}{$2 S C M L$} & \multicolumn{2}{|c|}{$2 \mathrm{SCML}$} \\
\hline & Coefficient & $S D$ & Coefficient & $S D$ \\
\hline \multicolumn{5}{|l|}{$\begin{array}{l}\text { Constant } \\
\text { Borrower's Risk }\end{array}$} \\
\hline Default $_{t+1}$ & 0.096 & $0.038 * *$ & 0.294 & $0.071 * * *$ \\
\hline \multicolumn{5}{|l|}{ Competition } \\
\hline Herfindahl $_{\mathrm{t}}$ & 0.003 & 0.003 & -0.008 & 0.006 \\
\hline \multicolumn{5}{|l|}{ Experience and prefs. of lender } \\
\hline Size of the lender ${ }_{t}$ & -0.018 & $0.003 * * *$ & -0.015 & $0.003 * * *$ \\
\hline Bank & -0.139 & $0.016^{* * *}$ & -0.180 & $0.047^{* * *}$ \\
\hline Specialisation $_{\mathrm{t}}$ & -0.016 & $0.001 * * *$ & -0.007 & $0.003 * * *$ \\
\hline \multicolumn{5}{|l|}{$\begin{array}{l}\text { Control Variables } \\
\quad \text { Economic conditions }\end{array}$} \\
\hline GDP growth $_{\mathrm{t}-1}$ & -0.086 & $0.004 * * *$ & -0.031 & $0.006 * * *$ \\
\hline $\mid$ GDPG $_{t-1}-$ Average GDPG $_{\mathrm{t}-1} \mid$ & 0.003 & 0.007 & -0.043 & $0.011^{* * *}$ \\
\hline Real interest rate ${ }_{t}$ & -0.007 & $0.003 * *$ & -0.062 & $0.006 * * *$ \\
\hline Geographic risk $t-1$ & -0.002 & 0.003 & 0.014 & $0.004 * * \star$ \\
\hline $\begin{array}{l}\text { Loan's characteristics } \\
\text { log(Size of the loan) }\end{array}$ & 0.750 & $0.086 * \star *$ & 0.809 & $0.132 * \star *$ \\
\hline Error log(Size of the loan) $(\lambda)$ & -0.024 & 0.086 & -0.257 & 0.132 * \\
\hline No. Observations & 254,755 & & 170,317 & \\
\hline \% collateralized & 58.20 & & 8.73 & \\
\hline $\log L$ & $-136,870$ & & $-42,420$ & \\
\hline$\chi^{2}$ covariates & 41,708 & & 13,668 & \\
\hline Pseudo $\mathrm{R}^{2}$ & 0.210 & & 0.159 & \\
\hline$\left(1+\lambda^{2}\right)^{-1 / 2}$ & 1.000 & & 0.969 & \\
\hline
\end{tabular}

Notes:

a. Each regression also includes 49 regional dummies and 10 industry dummies. The estimations obtained using the 2SCML methodology, have to be multiplied by the term $1 / \sqrt{1}+\hat{\lambda}^{2}$ to recover the original parameters. To allow the comparison between the logistic model and the $2 \mathrm{SCML}$ the parameters of the latter have been multiplied by 1.6 following Greene (1993).

b. $* * *$ associated variable significant at $1 \%, * *$ at $5 \%$, and $*$ at $10 \%$. 
Table 6

\section{Marginal effects}

Marginal changes in the probability of using collateral in a financial loan in the groups of Old and New Borrowers for changes in the explanatory variables of Risk of the Borrower, Concentration of lenders in the Geographic Market, Relationship Lending, Macroeconomic Conditions and Characteristics of the lender. Estimated using the Logit model with fixed effects for Old Borrowers and Probit model for New Borrowers. For the definition of the variables, see Table 1.

\begin{tabular}{|c|c|c|c|c|c|c|c|c|}
\hline & \multicolumn{4}{|c|}{ Old Borrowers. Fixed Effects } & \multicolumn{4}{|c|}{ New Borrowers } \\
\hline & Long Term & & Short term & & Long Term & & Short term & \\
\hline \multirow[t]{2}{*}{ Collateralised loans (\%) } & \multicolumn{2}{|l|}{50.25} & \multicolumn{2}{|l|}{29.67} & \multicolumn{2}{|l|}{58.20} & \multicolumn{2}{|l|}{8.73} \\
\hline & $\begin{array}{l}\text { Marginal } \\
\text { effect }\end{array}$ & $\begin{array}{l}\text { Semi- } \\
\text { elasticity } \\
(\%)\end{array}$ & $\begin{array}{l}\text { Marginal } \\
\text { effect }\end{array}$ & $\begin{array}{l}\text { Semi- } \\
\text { elasticity } \\
(\%)\end{array}$ & $\begin{array}{l}\text { Marginal } \\
\text { effect }\end{array}$ & $\begin{array}{l}\text { Semi- } \\
\text { elasticity } \\
(\%)\end{array}$ & $\begin{array}{l}\text { Marginal } \\
\text { effect }\end{array}$ & $\begin{array}{l}\text { Semi- } \\
\text { elasticity } \\
(\%)\end{array}$ \\
\hline \multicolumn{9}{|l|}{ Borrower's Risk } \\
\hline Default $_{\mathrm{t}-1}$ & 0.1037 & $20.6 * \star *$ & 0.1391 & $46.9 * * *$ & -- & -- & -- & -- \\
\hline Default $_{\mathrm{t}+1}$ & 0.0414 & $8.2 * \star \star$ & 0.0728 & $24.5^{\star \star \star \star}$ & 0.0228 & 3.9 ** & 0.0251 & $28.7 * \star \star$ \\
\hline \multicolumn{9}{|l|}{ Competition } \\
\hline Herfindahl $_{\mathrm{t}}$ & -0.0016 & $-0.3 * *$ & -0.0038 & $-1.3 * *$ & 0.0008 & 0.1 & -0.0006 & -0.7 \\
\hline \multicolumn{9}{|c|}{ Experience and preferences of lender } \\
\hline Size of the lender ${ }_{t}$ & -0.0065 & $-1.3 * * *$ & -0.0107 & $-3.6 * \star \star$ & -0.0042 & $-0.7^{* * \star}$ & -0.0011 & $-1.3 * \star \star$ \\
\hline Bank & -0.0868 & $-17.3 * \star *$ & -0.1139 & $-38.4 * \star *$ & -0.0334 & $-5.7 * * *$ & -0.0141 & -16.1 *** \\
\hline Specialisation $_{t}$ & -0.0017 & $-0.3 * * *$ & -0.0002 & -0.1 & -0.0037 & $-0.6 * \star \star$ & -0.0006 & -0.6 *** \\
\hline \multicolumn{9}{|l|}{ Relationship lending } \\
\hline Duration $_{\mathrm{t}-1}$ & -0.0025 & $-0.5 * \star \star$ & 0.0004 & 0.1 & -- & -- & -- & -- \\
\hline Scope $_{t-1}$ & -0.0116 & $-2.3 * * *$ & 0.0216 & $7.3 * * *$ & -- & -- & -- & -- \\
\hline Number of lenders $\mathrm{t}_{-1}$ & 0.0056 & $1.1 * \star *$ & -0.0053 & $-1.8 * * *$ & -- & -- & -- & -- \\
\hline \multirow{2}{*}{\multicolumn{9}{|c|}{$\begin{array}{l}\text { Control Variables } \\
\qquad \text { Economic conditions }\end{array}$}} \\
\hline & & & & & & & & \\
\hline GDP growth $_{\mathrm{t}-1}$ & -0.0180 & $-3.6 * \star \star$ & -0.0147 & $-4.9 * \star \star$ & -0.0207 & $-3.6 * \star \star$ & -0.0024 & -2.8 ** \\
\hline $\mid$ GDPG $_{t-1}-$ Average GDPG ${ }_{t-1} \mid$ & -0.0103 & $-2.1 * * *$ & -0.0172 & $-5.8^{* * *}$ & 0.0007 & 0.1 & -0.0033 & $-3.8 * \star *$ \\
\hline Real interest rate ${ }_{t}$ & -0.0066 & $-1.3 * * *$ & -0.0113 & $-3.8^{* * *}$ & -0.0016 & $-0.3 * *$ & -0.0048 & $-5.5 * * *$ \\
\hline $\begin{array}{l}\text { Geographic risk }{ }_{\mathrm{t}-1} \\
\quad \text { Firm's characteristics }\end{array}$ & 0.0018 & $0.4 * * *$ & 0.0054 & $1.8^{* * *}$ & -0.0004 & \multicolumn{2}{|c|}{ Firm's characteristics } & $1.2 * \star \star$ \\
\hline Debt $_{\mathrm{t}-1}$ & $-8 \mathrm{E}-07$ & $0.0 * * *$ & $-5 E-07$ & $0.0 *$ & -- & -- & -- & -- \\
\hline $\begin{array}{l}\text { "Age" as Borrower }{ }_{\mathrm{t}-1} \\
\text { Loan's characteristics }\end{array}$ & 0.0001 & 0.0 & 0.0000 & 0.0 & -- & -- & -- & -- \\
\hline Size of the loan & 0.0002 & $0.0 * * *$ & 0.0005 & $0.2 * \star *$ & 0.0008 & $0.1 * * *$ & 0.0007 & $0.8^{* \star \star}$ \\
\hline
\end{tabular}

Notes:

a. Estimated parameters for new borrowers have been transformed to recover the original ones of the structural equation. The estimated probability at sample mean is computed as $\mathrm{F}(\hat{\beta} \overline{\mathrm{x}})$, where $\bar{X}$ denotes the means of all the variables and $\hat{\beta}$ denotes the estimated parameters (multiplied by $1 / \sqrt{1+\hat{\lambda}^{2}}$ for new borrowers). The marginal effect is computed as $\frac{\mathrm{d}[\operatorname{Prob}(\mathrm{y}=1 \mid \mathrm{x})]}{\mathrm{dx}_{\mathrm{k}}}=\mathrm{f}(\hat{\beta} \overline{\mathrm{x}}) \hat{\beta}_{\mathrm{k}}$ for all the variables except for debt, "age" as borrower, duration, scope, number of lenders and size of the loan which is $\left(\mathrm{f}(\hat{\beta} \overline{\mathrm{x}}) \hat{\beta}_{\mathrm{k}}\right) / \overline{\mathrm{x}}_{\mathrm{k}}$, to recover the effect of these variables in levels. For the binary ones it is $\operatorname{Pr}\left(\right.$ Collateral $\left.=1 \mid \overline{\mathrm{x}}_{*}, \mathrm{~d}=1\right)-\operatorname{Pr}\left(\right.$ Collateral $\left.=1 \mid \overline{\mathrm{x}}_{*}, \mathrm{~d}=0\right)$, where $\bar{X}_{*}$ denotes the means of all the other variables. $F($.$) denotes the distribution function and f($.$) is its density function.$

b. $* * *$ associated variable significant at $1 \%$, ** at $5 \%$, and $*$ at $10 \%$. 
Table 7

\section{Determinants of the amount of collateral: Old Borrowers}

Results of the estimation of the determinants of the amount of collateral for a loan in year $t$ given the Risk of the Borrower, the Concentration in the Geographic Market, the Relationship between the lender and the borrower, and the Macroeconomic environment, the Characteristics of the Lender and the Size of the loan as control variables for the group of Old Borrowers. Multinomial Logit model. For the definition of the variables, see Table 1.

\begin{tabular}{|c|c|c|c|c|}
\hline \multirow[b]{2}{*}{ Variable } & \multicolumn{4}{|c|}{ Old Borrowers } \\
\hline & \multicolumn{2}{|c|}{ Long term } & \multicolumn{2}{|l|}{ Short term } \\
\hline Dependent Variable & \multicolumn{2}{|c|}{ Collateral (1/0) } & \multicolumn{2}{|c|}{ Collateral (1/0) } \\
\hline \multirow[t]{3}{*}{ Estimation } & \multirow{2}{*}{\multicolumn{2}{|c|}{$\begin{array}{l}\text { Multinomial Logit } \\
\text { Total vs. Partial Collateral }\end{array}$}} & \multirow{2}{*}{\multicolumn{2}{|c|}{$\begin{array}{l}\text { Multinomial Logit } \\
\text { Total vs. Partial Collateral }\end{array}$}} \\
\hline & & & & \\
\hline & Coefficient & $S D$ & Coefficient & $S D$ \\
\hline Constant & 21.937 & $1.567^{\star \star \star}$ & 14.533 & $2.192 * * *$ \\
\hline \multicolumn{5}{|l|}{ Borrower's Risk } \\
\hline Default $\mathrm{t}-1$ & -2.034 & $0.187 * \star \star$ & -1.429 & $0.377 * \star \star$ \\
\hline Default $t_{t+1}$ & -1.509 & $0.136 * * *$ & -0.925 & $0.207 * \star *$ \\
\hline \multicolumn{5}{|l|}{ Competition } \\
\hline Herfindahl $_{\mathrm{t}}$ & -0.133 & $0.016 * \star \star$ & -0.120 & $0.025 * * *$ \\
\hline \multicolumn{5}{|l|}{ Experience and prefs. of lender } \\
\hline Size of the lender ${ }_{t}$ & 0.307 & $0.014 * * *$ & 0.246 & $0.022 * * *$ \\
\hline Bank & -1.237 & $0.105^{* \star \star}$ & -2.172 & $0.381 * \star \star$ \\
\hline Specialisation $_{\mathrm{t}}$ & 0.047 & $0.005 * * *$ & 0.077 & $0.017 * * *$ \\
\hline \multicolumn{5}{|l|}{ Relationship lending } \\
\hline $\log \left(\right.$ Duration $\left._{t-1}\right)$ & -0.002 & 0.038 & 0.380 & $0.121 * \star *$ \\
\hline $\log \left(\right.$ Scope $\left._{t-1}\right)$ & -1.269 & $0.078 * \star \star$ & -1.385 & $0.236 * \star \star$ \\
\hline $\log \left(\right.$ Number of lenders $\left.t_{t-1}\right)$ & -5.050 & $0.460 * * *$ & -5.748 & $1.147^{* * *}$ \\
\hline \multicolumn{5}{|l|}{$\begin{array}{l}\text { Control Variables } \\
\quad \text { Economic conditions }\end{array}$} \\
\hline GDP growth ${ }_{t-1}$ & 0.005 & 0.018 & 0.014 & 0.026 \\
\hline $\mid G G_{t-1}-A_{\text {verage }}$ GDPG $_{t-1} \mid$ & 0.155 & $0.027 * * \star$ & 0.171 & $0.053 * * *$ \\
\hline Real interest rate ${ }_{t}$ & 0.067 & $0.010 * \star \star$ & 0.191 & $0.038 * \star \star$ \\
\hline Geographic risk t-1 & 0.009 & 0.009 & 0.010 & 0.017 \\
\hline \multicolumn{5}{|l|}{ Firm's characteristics } \\
\hline $\log \left(\right.$ Debt $\left._{t-1}\right)$ & 3.285 & $0.307 * \star \star$ & 3.845 & $0.828 * \star \star *$ \\
\hline $\log \left(“ A g e\right.$ " as Borrower ${ }_{\mathrm{t}-1}$ ) & 0.395 & $0.047 * * \star$ & 0.636 & $0.114 * \star \star$ \\
\hline \multicolumn{5}{|l|}{ Loan's characteristics } \\
\hline $\log$ (Size of the loan) & -6.105 & $0.571 * * *$ & -6.473 & $1.451 * * \star$ \\
\hline Error log(Size of the loan) $(\lambda)$ & 7.695 & $0.679 * * \star$ & 7.122 & 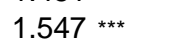 \\
\hline No. Observations & 823,340 & & 723,924 & \\
\hline$\%$ fully collateralised & 50.57 & & 7.48 & \\
\hline Log $L$ & $-548,617$ & & $-210,072$ & \\
\hline$\chi^{2}$ covariates & 242,194 & & 54,551 & \\
\hline Pseudo $\mathrm{R}^{2}$ & 0.181 & & 0.115 & \\
\hline$\left(1+\lambda^{2}\right)^{-1 / 2}$ & 0.129 & & 0.139 & \\
\hline
\end{tabular}

a. Each regression also includes 49 regional dummies and 10 industry dummies. The estimations obtained using the $2 \mathrm{SCML}$ methodology, have to be multiplied by the term $1 / \sqrt{1+\hat{\lambda}^{2}}$ to recover the original parameters. To allow the comparison between the logistic model and the 2SCML the parameters of the latter have been multiplied by 1.6 following Greene (1993).

b. $* * *$ associated variable significant at $1 \%, * *$ at $5 \%$, and $*$ at $10 \%$. 
Table 8

Predicted probabilities of Default in $t+1$

Conditional probability (\%) that the borrower will default in period $t+1$ given that the loan granted in period $\mathrm{t}-1$ had collateral

Old Borrowers

New Borrowers

Long Term Short Term $\quad$ Long Term Short Term

Average Probability of Defualt in $t+1$ for the population (from Tables 2 and 3)

7.32

9.96

9.12

17.37

Conditional Probability of Default in $\mathrm{t}+1$ given that the Loan is Collateralised

$8.03 \quad 15.03$

9.46 24.09

Note: For example, the figure of $15.03 \%$ is obtained as follows. The $\operatorname{Pr}\left(\right.$ Collateral/Default $\left.t_{t+1}\right)$ is obtained from the date with all other variables at their sample means and is equal to $11.47 \%$. The marginal probability of default is $\operatorname{Pr}\left(\right.$ Default $\left._{t+1}\right)=9.96 \%$. Therefore the joint probability of Collateral and Default will be $\operatorname{Pr}($ Collateral and Default $)=1.14 \%$. Since the marginal probability of Collateral is, for the variables at their sample means, $\operatorname{Pr}($ Collateral $)=7.60 \%$, the conditional probability of Default given Collateral is equal to $\operatorname{Pr}\left(\right.$ Default $t_{t+1} /$ Collateral $)=1.14 / 7.60=0.1503$. 
BANCO DE ESPAÑA PUBLICATIONS

\author{
WORKING PAPERS ${ }^{1}$
}

0216 ALICIA GARCÍA HERRERO, JAVIER SANTILLÁN, SONSOLES GALLEGO, LUCÍA CUADRO AND CARLOS EGEA: Latin American Financial Development in Perspective.

0217 SONSOLES GALLEGO, ALICIA GARCÍA HERRERO AND JESÚS SAURINA: The Asian and European Banking Systems: The case of Spain in the Quest for Development and Stability.

0218 JOSÉ RAMÓN MARTÍNEZ RESANO AND LILIANA TOLEDO FALCÓN: Futuros sobre acciones: Demanda e implicaciones sobre los mercados de renta variable.

0219 JOSÉ MANUEL CAMPA AND JOSÉ M. GONZÁLEZ MÍNGUEZ: Differences in exchange Rate Pass-Through in the Euro Area.

0220 LUIS JULIÁN ÁLVAREZ GONZÁLEZ AND JAVIER JAREÑO MORAGO: ISIS, Un indicador sintético integral de los servicios de mercado.

0221 MARCO HOEBERICHTS: The Credibility of Central Bank Announcements.

0222 KLAUS DESMET: Asymmetric Shocks, Risk Sharing, and the Latter Mundell.

0223 JOSÉ MANUEL CAMPA AND IGNACIO HERNANDO: Value creation in European M\&As.

0224 JUAN AYUSO HUERTAS, DANIEL PÉREZ CID AND JESÚS SAURINA SALAS: Are capital buffers pro-cyclical? Evidence from Spanish panel data.

0225 ANDREW BENITO: Does job insecurity affect household consumption?

0226 ANDREW BENITO: Financial pressure, monetary policy effects and inventory adjustment by UK and Spanish firms.

0227 ANDREW BENITO AND IGNACIO HERNANDO: Extricate: Financial Pressure and Firm Behaviour in Spain.

0228 ANA DEL RÍO, El endeudamiento de los hogares españoles.

0229 GABRIEL PÉREZ QUIRÓS AND JORGE SICILIA: Is the European Central Bank (and the United States Federal Reserve) predictable?

0301 JAVIER ANDRÉS, EVA ORTEGA AND JAVIER VALLÉS: Market structure and inflation differentials in the European Monetary Union.

0302 JORDI GALÍ, MARK GERTLER AND J. DAVID LÓPEZ-SALIDO: The euro area inefficiency gap.

0303 ANDREW BENITO, The incidence and persistence of dividend omissions by Spanish firms.

0304 JUAN AYUSO AND FERNANDO RESTOY: House prices and rents: an equilibrium asset pricing approach.

0305 EVA ORTEGA, Persistent inflation differentials in Europe.

0306 PEDRO PABLO ÁLVAREZ LOIS: Capacity utilization and monetary policy.

0307 JORGE MARTÍNEZ PAGÉS AND LUIS ÁNGEL MAZA: Analysis of house prices in Spain. (The Spanish original of this publication has the same number).

0308 CLAUDIO MICHELACCI AND DAVID LÓPEZ-SALIDO: Technology shocks and job flows.

0309 ENRIQUE ALBEROLA: Misalignment, liabilities dollarization and exchange rate adjustment in Latin America.

0310 ANDREW BENITO: The capital structure decisions of firms: is there a pecking order?

0311 FRANCISCO DE CASTRO: The macroeconomic effects of fiscal policy in Spain.

0312 ANDREW BENITO AND IGNACIO HERNANDO: Labour demand, flexible contracts and financial factors: new evidence from Spain.

0313 GABRIEL PÉREZ QUIRÓS AND HUGO RODRÍGUEZ MENDIZÁBAL: The daily market for funds in Europe: what has changed with the EMU?

0314 JAVIER ANDRÉS AND RAFAEL DOMÉNECH: Automatic stabilizers, fiscal rules and macroeconomic stability

0315 ALICIA GARCÍA HERRERO AND PEDRO DEL RÍO: Financial stability and the design of monetary policy.

0316 JUAN CARLOS BERGANZA, ROBERTO CHANG AND ALICIA GARCÍA HERRERO: Balance sheet effects and the country risk premium: an empirical investigation.

0317 ANTONIO DÍEZ DE LOS RÍOS AND ALICIA GARCÍA HERRERO: Contagion and portfolio shift in emerging countries' sovereign bonds.

0318 RAFAEL GÓMEZ AND PABLO HERNÁNDEZ DE COS: Demographic maturity and economic performance: the effect of demographic transitions on per capita GDP growth.

0319 IGNACIO HERNANDO AND CARMEN MARTÍNEZ-CARRASCAL: The impact of financial variables on firms' real decisions: evidence from Spanish firm-level data.

1. Previously published Working Papers are listed in the Banco de España publications calalogue. 
0320 JORDI GALÍ, J. DAVID LÓPEZ-SALIDO AND JAVIER VALLÉS: Rule-of-thumb consumers and the design of interest rate rules.

0321 JORDI GALÍ, J. DAVID LÓPEZ-SALIDO AND JAVIER VALLÉS: Understanding the effects of government spending on consumption.

0322 ANA BUISÁN AND JUAN CARLOS CABALLERO: Análisis comparado de la demanda de exportación de manufacturas en los países de la UEM.

0401 ROBERTO BLANCO, SIMON BRENNAN AND IAN W. MARSH: An empirical analysis of the dynamic relationship between investment grade bonds and credit default swaps.

0402 ENRIQUE ALBEROLA AND LUIS MOLINA: What does really discipline fiscal policy in emerging markets? The role and dynamics of exchange rate regimes.

0403 PABLO BURRIEL-LLOMBART: An economic analysis of education externalities in the matching process of UK regions (1992-1999).

0404 FABIO CANOVA, MATTEO CICCARELLI AND EVA ORTEGA: Similarities and convergence in G-7 cycles.

0405 ENRIQUE ALBEROLA, HUMBERTO LÓPEZ AND LUIS SERVÉN: Tango with the gringo: the hard peg and real misalignment in Argentina.

0406 ANA BUISÁN, JUAN CARLOS CABALLERO AND NOE LIA JIMÉNEZ: Determinación de las exportaciones de manufacturas en los países de la UEM a partir de un modelo de oferta-demanda.

0407 VÍTOR GASPAR, GABRIEL PÉREZ QUIRÓS AND HUGO RODRÍGUEZ MENDIZÁBAL: Interest rate determination in the interbank market.

0408 MÁXIMO CAMACHO, GABRIEL PÉREZ-QUIRÓS AND LORENA SAIZ: Are European business cycles close enough to be just one?

0409 JAVIER ANDRÉS, J. DAVID LÓPEZ-SALIDO AND EDWARD NELSON: Tobin's imperfect assets substitution in optimizing general equilibrium.

0410 A. BUISÁN, J. C. CABALLERO, J. M. CAMPA AND N. JIMÉNEZ: La importancia de la histéresis en las exportaciones de manufacturas de los países de la UEM

0411 ANDREW BENITO, FRANCISCO JAVIER DELGADO AND JORGE MARTíNEZ PAGÉS: A synthetic indicator of financial pressure for Spanish firms.

0412 JAVIER DELGADO, IGNACIO HERNANDO AND MARÍA J. NIETO: Do European primarily Internet banks show scale and experience efficiencies?

0413 ÁNGEL ESTRADA, JOSÉ LUIS FERNÁNDEZ, ESTHER MORAL AND ANA V. REGIL: A quarterly macroeconometric model of the Spanish economy.

0414 GABRIEL JIMÉNEZ AND JESÚS SAURINA: Collateral, type of lender and relationship banking as determinants of credit risk.

0415 MIGUEL CASARES: On monetary policy rules for the euro area.

0416 MARTA MANRIQUE SIMÓN AND JOSÉ MANUEL MARQUÉS SEVILLANO: An empirical approximation of the natural rate of interest and potential growth. (The Spanish original of this publication has the same number)

0417 REGINA KAISER AND AGUSTíN MARAVALL: Combining filter design with model-based filtering (with an application to business-cycle estimation).

0418 JÉRÔME HENRY, PABLO HERNÁNDEZ DE COS AND SANDRO MOMIGLIANO: The short-term impact of government budgets on prices: evidence from macroeconometric models.

0419 PILAR BENGOECHEA AND GABRIEL PÉREZ-QUIRÓS: A useful tool to identify recessions in the euro-area.

0420 GABRIEL JIMÉNEZ, VICENTE SALAS AND JESÚS SAURINA: Determinants of collateral.

\section{BANCODEESPAÑA}

Unidad de Publicaciones Alcalá, 522; 28027 Madrid

Telephone +3491338 6363. Fax +34913386488 e-mail: Publicaciones@bde.es www.bde.es 

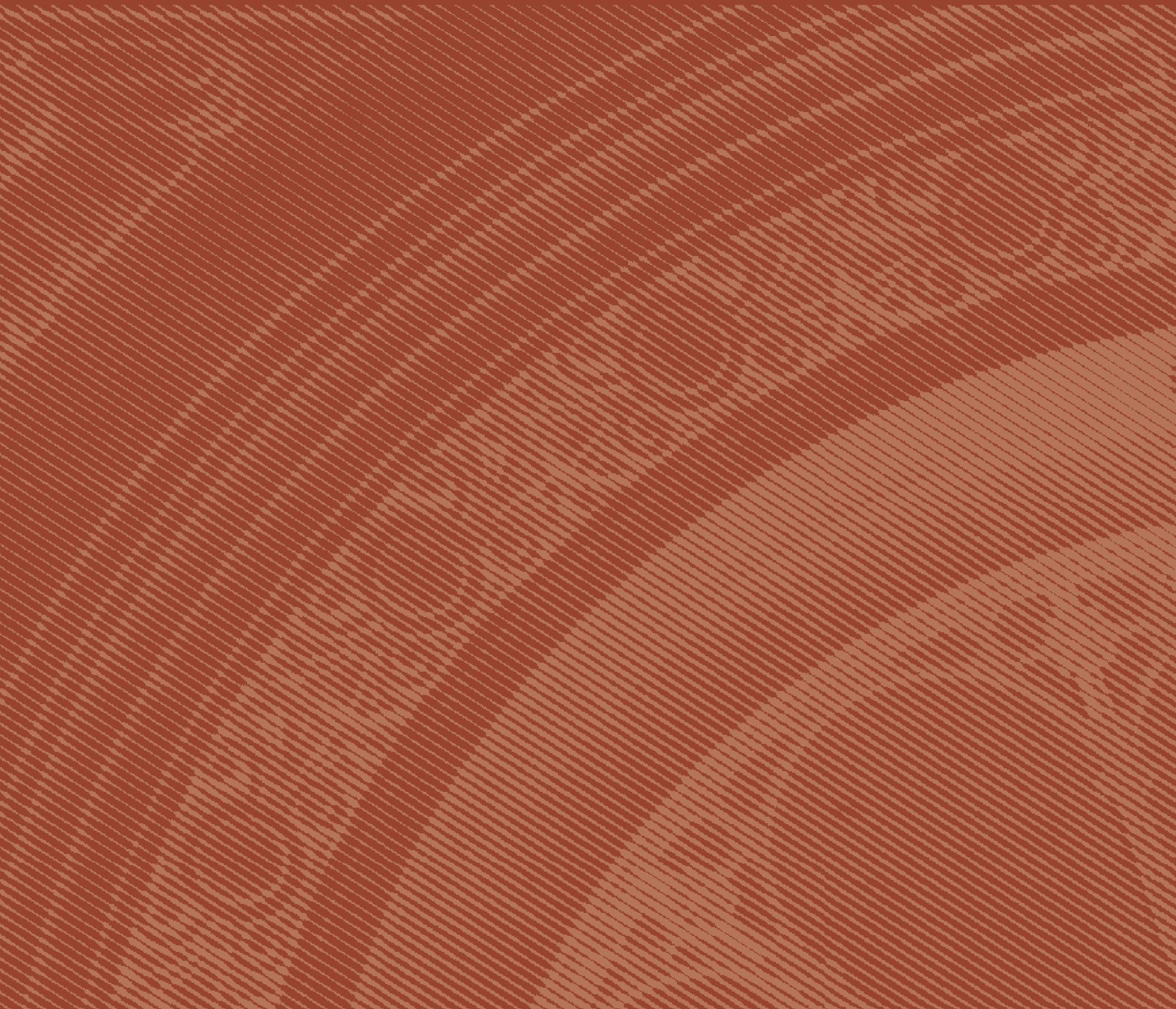

.

20

171017

1101010

1111111

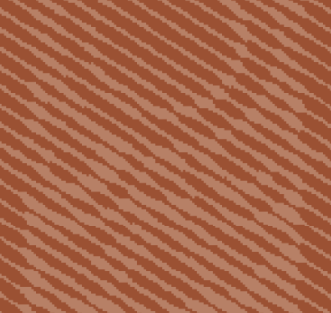
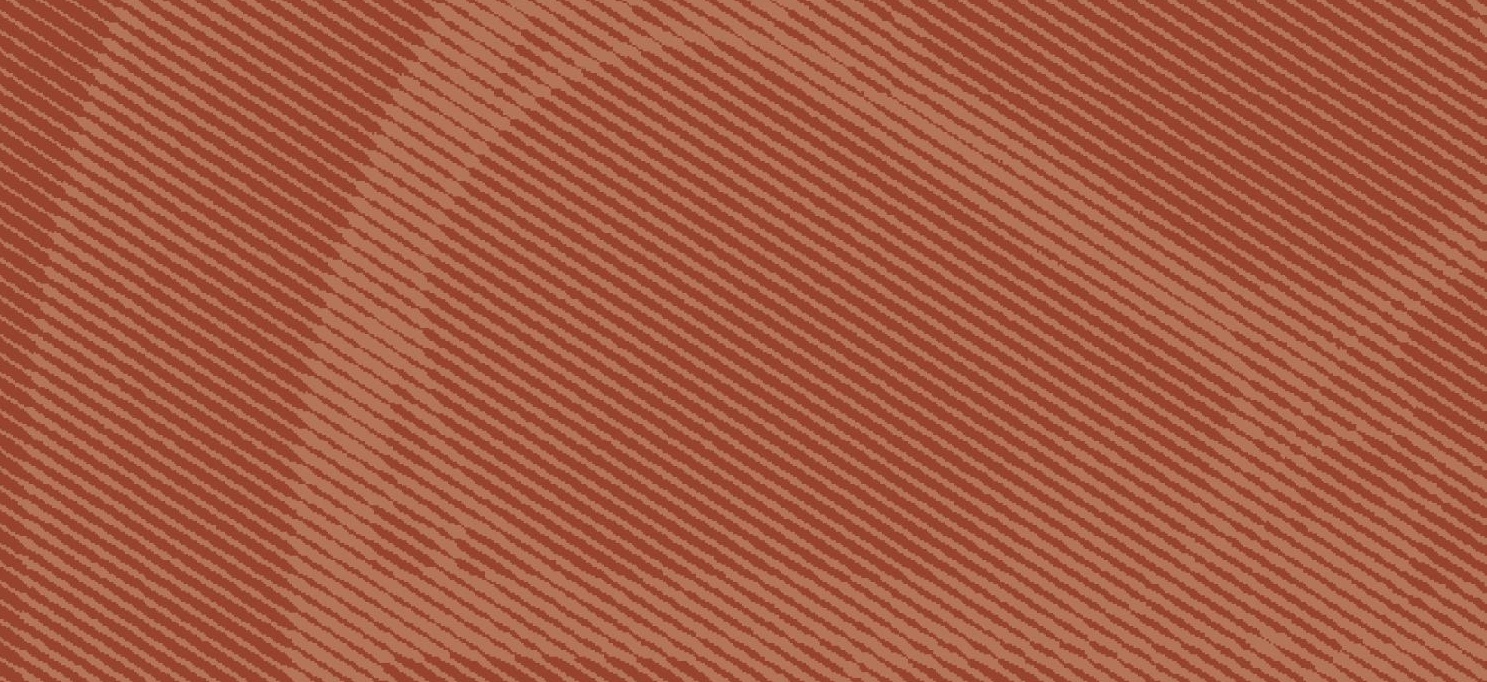

$1 \times 1010$
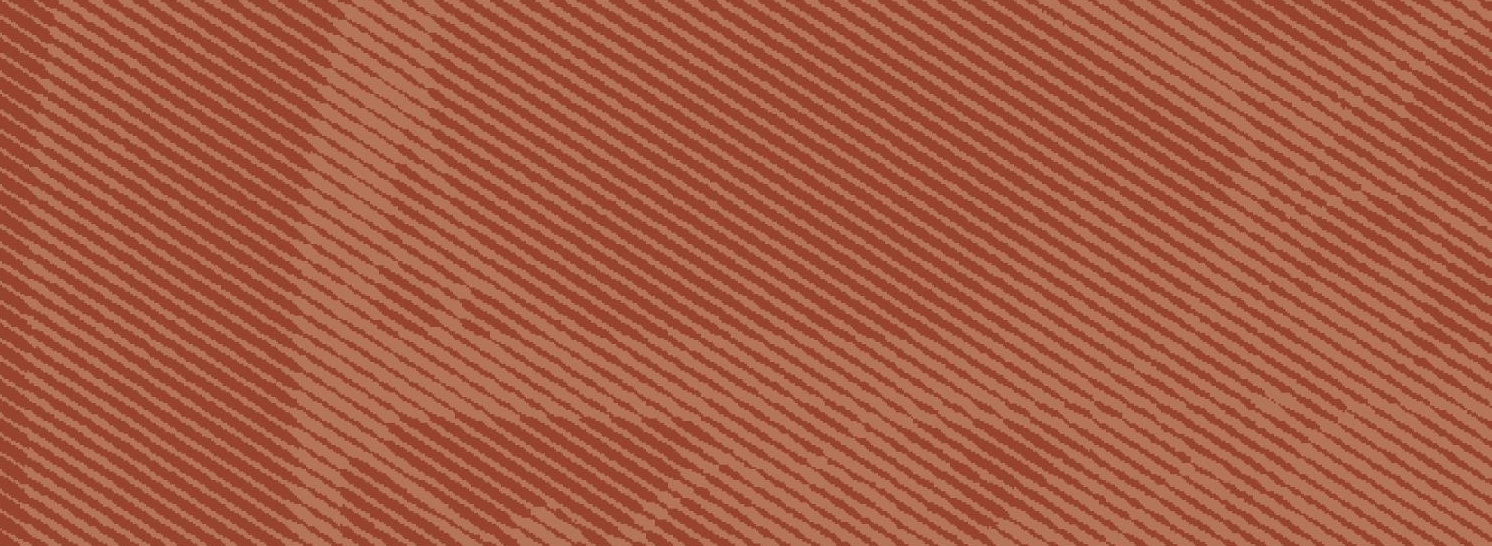
\M W N N W $N$ N N N N N N N N N N W N N N N W N W N L 